\title{
11 Eylül Terör Saldırıları Sonrası ABD Gayrinizami Harp Anlayışının Değişimi
}

\author{
The Change of US Irregular Warfare Approach \\ after the 9/11 Terror Attacks
}

\author{
Emrah ÖZDEMİ*
}

\section{$\ddot{O} z$}

Gayrinizami harp tecrübesi anlaminda ABD silahl kuvvetlerinin kazanmmlarn 18.yüzynla kadar uzanmaktadr. Ancak dönemsel olarak Vietnam Savaşı gibi travmatik olaylar bu tür kıymetli tecrübelerin göz ardı edilmesine ve uzunca bir süre gayrinizami harbe temkinli bir şekilde yaklaşılmasına yol açmısttr. Bu çalşsmada tarihsel süreçte $A B D$ için en trajik tecrübelerin bassinda gelen 11 Eylül Saldmlar sonrası ABD Ordusunun gayrinizami harp doktrininin nasıl şekillendiği ve güncel stratejik düsüncede ne anlam ifade ettiği ortaya konulmaktadrr. Resmî belgeler, askerî talimnameler ve literatürde yaşanan tartışmalar ısı̆ğinda $A B D$ 'nin değişen güvenlik konsepti içerisinde, gayrinizami harbin ne derece önemli bir unsur olduğunu anlamak, çalısmanin temel amacın oluşturmaktadir. Bu anlamda çalışmann yöntemi nitel doküman incelemesi olarak belirlenmistir. Chalısmanin sonunda, konvansiyonel ordularn politik hedeflere ulaşmak için gayrinizami yaklaşımlara yoğunlaştılarn ve konvansiyonel olanla gayrinizami olan arasındaki farkın giderek muğlaklaştığ bir dönemin yaşandiğ ileri sürülmektedir.

Anahtar Kelimeler: Gayrinizami Harp, Konvansiyonel Harp, Güvenlik Yaklaşımları, ABD, Hibrit Savass.

\section{Abstract}

The experience of the US armed forces in terms of irregular warfare goes back to the 18th century. However, periodically, traumatic events such as the Vietnam War led

\footnotetext{
* Doç. Dr., Çankırı Karatekin Üniversitesi İktisadi ve İdari Bilimler Fakültesi Uluslararası İlişkiler Bölümü, Çankırı, Türkiye, ORCID: 0000-0001-8125-6486, e-posta: emrahozdemir@karatekin.edu.tr.
}

Geliş Tarihi / Submitted: 20.11.2020

Kabul Tarihi / Accepted: 26.07.2021 
to such valuable experiences to be ignored and to approach irregular war with caution. In this study, how the US Army's irregular war doctrine was shaped after the September 11 attacks and what it means in current strategic thinking is presented. Understanding the importance of irregular warfare in the changing security concept of the USA in the light of official documents, military manuals and discussions in the literature constitutes the main purpose of the study. In this sense, the method of the study was determined as qualitative document analysis. At the end of the study, it is argued that a period, in which conventional armies focus on irregular approaches to achieve political goals, and the difference between the conventional and the irregular is blurred, is experienced.

Keywords: Irregular Warfare, Conventional Warfare, Security Approaches, USA, Hybrid Warfare.

\section{Giriş}

Gayrinizami harp (GNH) kavramı en genel anlamıla iki ya da daha fazla devletin orduları arasında cereyan eden, düzenli muharebeler dışında kalan, politik amaçlı silahlı çatışmalar ya da kuvvet kullanımı olarak değerlendirildiğinde, ABD Ordusunun bu alandaki tecrübesinin Amerikan İç Savaşı dönemine, hatta Bağımsızlık Savaşı'na kadar uzandığı söylenebilir. Ancak kavramın modern anlamıyla sistematik olarak Amerikan askerî yapılanması içerisine dâhil olması -Filipinler'de ciddi tecrübeler yaşanmasına rağmen- İkinci Dünya Savaşı dönemine rastlamaktadır. Bu dönemde Alman hatlarının gerisinde istihbarat elde etme, espiyonaj ve sabotaj faaliyetleri ile yerel direnişlerin örgütlenmesi gibi farklı fonksiyonları yerine getirmek maksadiyla Stratejik Hizmetler Ofisi [Office of Strategic Services (OSS)] altında Operasyonel Grup Komutanlığı (Operational Group Command)'nın teşkili dikkat çekicidir. ${ }^{1}$

Vietnam Savaşı'nda ise konvansiyonel ordu birlikleri ile yürütülemeyeceği değerlendirilen mücadelelerin, zaman zaman halk merkezli ayaklanmaya karşı koyma (counterinsurgency) harekâtına dönüştüğü görülmektedir. Bu yeni yaklaşıma göre ayaklanmaya karşı koyma harekâtı sadece özel kuvvetler tarafından yürütülen bir faaliyet olmanın ötesinde, tüm ABD Ordusu tarafından yürütülmesi gereken kapsamlı mücadele olarak tanımlanmaktaydı.

1 Office of Strategic Services, Operational Group Command, OSS Presentation, Washington D.C., 1944. 
Elde edilen tecrübeler askerî literatüre dönem içerisinde yazılan FM 31-15 Gayrinizami Kuvvetlere Karşı Harekât (Operations Against Irregular Forces), FM 31-16 Kontrgerilla Harekâtları (Counterguerrilla Operations) ve FM 31-22 (A) ABD Ordusu Ayaklanmaya Karş1 Koyma Kuvvetleri (US Army Counterinsurgency Forces) isimli talimnameler üzerinden girmiştir. Teorik ve pratik anlamda Vietnam tecrübesi ABD ordusuna gerek yap1 gerekse doktrin anlamında önemli kazanımlar getirmiş olmakla birlikte yaşanan yenilginin politik ve toplumsal olumsuzlukları ABD ordusunun uzunca bir süre bu tarz geniş kapsamlı harekâtlara şüpheyle yaklaşmasına neden olmuştur. ${ }^{2}$

Soğuk Savaş'ın son döneminde ise karşılıklı silahlanma yarış1, Sovyetler Birliği'nin beklenmedik şekilde dağılması ile yerini savaş ve çatışma anlamında yeni bir döneme bırakmıştır. Bu yeni dönemde ortaya çıkan etnik çatışma, ayaklanma ve istikrarsız yönetimler Vietnam ile geri planda kalan GNH kavramını tekrar ön plana çıkarmıştır. Soğuk Savaş’tan galip çıktı̆̆ ilan edilen ABD Ordusu, Askerî Alanda Devrim (Revolution in Military Affairs) bakış açısını benimseyen askerî uzmanlar ve stratejistlerce bu dönemde teknolojik üstünlüğe dayalı yapısı ile dünyanın en üstün konvansiyonel ordusu olarak değerlendirilmekteydi. ${ }^{3}$ Dahası bu konvansiyonel ordu, teknolojik imkânlarını ve doktrin anlamında üstünlügünü kanıtlama fırsatı bulamamıs olmanın verdiği hevesle, farklı test alanları aramaktaydı. Irak'ın Kuveyt'i işgali bu test imkânını yaratmıs ve kısa sürede tüm dünyanın gözü önünde cereyan eden savaş, ABD’nin stratejik ve operatif seviyede konvansiyonel gücünü tescilleyen bir zafer olarak sunulmuştur. Konvansiyonel üstünlüğe dayalı bu savaş esnasında da GNH tali unsur olarak görülmüştür.

Ancak $\mathrm{ABD}$ ordusunun bu başarılarla perçinlenen konvansiyonel zırhında Somali'de on sekiz ABD askerinin ölümü ile ciddi bir delik açllır. Konvansiyonel anlamda yenilmez olarak görülen ABD ordusu yine gayrinizami bir çatışma içerisinde zayiat verir. Uğranılan bu kayba ve

2 Thomas R. Mockaitis, Trends in American Counterinsurgency, in The Routledge Handbook of Insurgency and Counterinsurgency, ed. Paul B. Rich and Isabelle Duyvestey, Routledge, New York, 2012, p. 251.

${ }^{3}$ Andrew F. Krepinevich, The Military-Technical Revolution: A Preliminary Assessment, Center for Strategic and Budgetary Assessments, Washington D.C., 2002. 
uluslararası itibar zedelenmesine tepki olarak 11 Eylül Saldırılarına kadar bu tür harekâtlara karşı temkinli yaklaşıldı ve ara birlikleri ile doğrudan katılım sağlanmadı. Saldırıların ardından GNH'ı konvansiyonel harbin destekleyicisi olarak değerlendiren bakış açısının süratle değiştirilmesine dayalı yeni ayaklanmaya karşı koyma yaklaşımı, halk merkezli bir anlayışla Irak ve Afganistan'daki mücadelelerin hâkim konsepti haline geldi. Ancak bu mücadele ve teorik yaklaşımların beklenen etkiyi gösterememesi ayaklanmaya karşı koyma şeklinde kendisini gösteren $\mathrm{GNH}$ faaliyetlerine bir kez daha temkinli yaklaşılmasına sebep olmuştur. Kapsamlı devlet inşası faaliyetlerinin yerini Suriye gibi bölgelerde sayıca küçük özel birlikler eliyle yerel unsurların yönlendirilmesi ve bu yerel unsurların politik anlamda da destek verilerek kontrolünün sağlanması şeklinde daha az riskli ve ekonomik bir yönteme dönüldügü görülmektedir.

$\mathrm{Bu}$ çalışmada, genel hatları ile belirtilen süreçler doğrultusunda 11 Eylül Saldırıları sonrası ABD Ordusunun GNH doktrininin nasıl şekillendiği ve güncel stratejik düşüncede ne anlam ifade ettiği ortaya konulmaktadır. ABD'nin değişen güvenlik konsepti içerisinde gayrinizami harbin ne derece önemli bir unsur olduğunu anlamak, çalışmanın temel amacını oluşturmaktadır. Çalışma üç bölümden oluşmaktadır. Birinci bölümde, 11 Eylül Saldırıları öncesinde ABD'nin GNH yaklaşımı ve silahlı kuvvetler içerisinde GNH unsurlarının yeri incelenmektedir. İkinci bölümde, Afganistan ve Irak'ın işgali sonrasında yaşanan değişim ve GNH'ın yükselişi ele alınmaktadır. Üçüncü bölümde ise, kapsamlı devlet inşası faaliyetlerine şüpheyle yaklaşan ve yerel unsurların kullanılmasına dayalı güncel bakış açıları ortaya konulmakta; müteakiben çalışma, bu üç bölümden elde edilen bulgular kullanılarak oluşturulan tespit, değerlendirme ve görüşlerin yer aldığı sonuç bölümü̈ ile nihayetlendirilmektedir.

Çalışmada ABD ordusunun GNH anlayışındaki değişimin ortaya konulabilmesi için doküman incelemesi yöntemi seçilmiştir. Bu maksatla ABD ordu talimnameleri ve Savunma Bakanlığı dört yıllık değerlendirme raporları gibi resmî belgeler GNH kavramı odaklı olarak incelenmiştir. Bu değişimin hangi olaylardan kaynaklandığının anlaşılabilmesi için dönemin konjonktürünü yansıttığı düşünülen akademik değerlendirmeler, kitaplar, medya yorum ve haberleri de incelemeye dâhil edilmiştir. Bu kaynaklar aynı zamanda doktrin anlamında yaşanan değişimin sahaya ne şekilde yansıdığını görebilme imkânı da tanımıştır. Belirtilen dokümanlar başarısız 
devlet, ayaklanma ve ayaklanmaya karşı koyma, GNH, ulusal çıkar, halk merkezli yaklaşım gibi temalar üzerinden incelenerek betimsel bir analiz ortaya konulmuştur.

1. 11 Eylül Şafağında ABD Güvenlik Değerlendirmeleri ve Askerî Yapılanma

Soğuk Savaş'ın konvansiyonel yaklaşımını üzerinden atamayan ABD Ordusu, 11 Eylül öncesi dönemde sayıca küçültülse de profesyonel bir personel planlaması ve teknolojik imkân-kabiliyetlere dayalı modern bir yaklaşımla güçlendirilmeye çalışılmıştır. Somali'nin ardından Ruanda ve Balkanlar'daki çatışma ve insani dramlar karşısında takınılan pasif tutum bu konvansiyonel yaklaşımdan kaynaklı ataletin, $\mathrm{ABD}$ ordu ve bürokrasisinde korunmakta olduğunu göstermiştir. 1990'ların sonlarına doğru Orta Doğu'daki başarısız devletleri kendilerine güvenli alan olarak belirleyen fundamentalist terör yapılanmaları hiç olmadıkları kadar etkili olmaya başladılar. 1998 yılı ABD Büyükelçilik Bombalamaları (Tanzanya, Kenya, Sudan) ve 2000 y1lında Yemen'de bulunan USS Cole Savaş Gemisine yönelik bombalı saldırı ABD ordusunun karakteri değişen yeni bir savaşla karşı karşıya kalacağı düşüncesinin en belirgin sinyallerini vermekteydi. Fakat bu yeni savaşa karşı bürokratik karar mekanizmalarının, istihbarat teşkilatlarının ve ordunun yeterince hazırlıklı olmadıkları 11 Eylül Saldırıları ile net bir şekilde görüldü.

ABD ordusunun ulusal güvenliğe yönelik bu yeni tehditlere karş1 takındığı tutum, 1990'larda olduğundan çok da farklı değildi. 1990 yılında Kuveyt'i işgali nedeniyle Irak'a yapılan müdahale, 2001 yılında Afganistan ve 2003 yılında Irak'ta da teknolojik değişim çerçevesinde benzer şekilde tekrarlanmıştır. Konvansiyonel üstünlüğe ve silah teknolojilerine dayalı bu yaklaşım doğrultusunda GNH birliklerinin görevi hedef tespiti, istihbarat toplama ve harekâtın devamında yerel unsurların yönlendirilmesi şeklinde gerçekleşti. Uygulanan bu doktrin 2001 öncesi dönemde kabul edilen yaklaşımlara dayanmaktaydı. 1998 yılı basımlı JP 3-05 Özel Operasyonlar Talimnamesi incelendiğinde, GNH kavramına kısıtlı bir alan tanındığ halen konvansiyonel savaşın bir destek unsuru olarak görüldüğü göze çarpmaktadır. $\mathrm{Bu}$ talimnamede belirtilen özel operasyon birliklerinin gerçekleştireceği harekât türleri ile Afganistan'ın işgalinde küçük birliklerle yürütülen GNH faaliyetleri birebir örtüşmektedir. Talimnameye göre bu faaliyetler; doğrudan muharebe görevi, özel keşif faaliyetleri, kitle imha 
silahlarının önlenmesi, terörle mücadele, konvansiyonel olmayan savaş (unconventional warfare), ayaklanmaya karşı koyma, insani yardım, bilgi destek harekâtı, istihbarat faaliyetleri ile sivil asker iş birliği faaliyetleri gibi oldukça geniş bir alanı kapsamaktadır. ${ }^{4}$

1990'lı yıllarda ABD Ordusunun GNH yaklaşımını anlamak için Somali'de yaşananlar önemli bir örnek olarak ele alınabilir. Ülkede düzen ve istikrarın sağlanabilmesi için en etkili savaş ağalarından (warlords) birisi olan Mohammed Farah Aidid'in etkisiz hale getirilmesi gerekmekteydi. Bu maksatla Ordu Rangerları ve Delta Kuvvetlerinden oluşan özel bir görev kuvveti (Task Force Ranger) oluşturuldu. Bu birliklerce 3-4 Ekim 1993 tarihinde Aidid ile ilişkili kişilerin yakalanması için düzenlenen harekât, iki Skorsky genel maksat helikopterinin düşmesi ve $18 \mathrm{ABD}$ askerinin ölümüyle tam bir fiyaskoya dönüştü. $\mathrm{Bu}$ sonuç hem $\mathrm{ABD}$ askerlerinin Somali'deki varlığını sonlandırdı hem de Vietnam sonrasında ilk kez bu kadar etkin bir biçimde istikrar harekâtı ve insani müdahale biçiminde yeniden uygulanan GNH konusuna karş1 temkinli duruşu pekiştirdi. ${ }^{5}$ ABD Ordusunun ülkenin dış politikası doğrultusunda yabancı ülkelerde icra ettiği bu konvansiyonel savaş dışı harekâtlara karşı çekinik bir tavır takınmasının bir diğer örneği de; Haiti'de Jean-Bertrand Aristide'nin tekrar ülke yönetimini ele geçirmesine yönelik gerçekleştirilen askerî müdahaledir. ${ }^{6}$

Zayiat vermeye karşı hiçbir şekilde tolerans gösteremeyen ve teknolojik üstünlükle zayiatı en aza indirmeyi esas kabul eden ABD Ordusu, 1990'ların sonunda hava gücüne dayalı, akıllı mühimmat kullanabilme ve üstün hareket kabiliyetine sahip bir askerî yapıyı, dönemin güvenlik tehditleri için uygun görmekteydi. Ancak her ne kadar teknolojik imkânlar ve ateş üstünlüğü en üst seviyede olsa da değişen diş politika ve güvenlik algılaması doğrultusunda başarısız devletlerde istikrarın sağlanması, düzensiz silahlı gruplarla mücadele ve devlet/ulus inşası gibi konvansiyonel

\footnotetext{
${ }^{4}$ JP3-05, Special Operations, Joint Chiefs of Staff, Washington D.C., 1998.

${ }^{5}$ Rick Atkinson, Night of a Thousand Casualties, Washington Post 1994, https://wapo.st/3m337sH (Erişim Tarihi: 18.08.2020); Steven Metz and Raymond Millen, Insurgency and Counterinsurgency in the 21st Century: Reconceptualizing Threat and Response, Strategic Studies Institute, U.S. Army War College, Carlisle, PA, 2004.

${ }^{6}$ Christopher E. Fowler, Forgeting Lessons Learned: The United States Army's Inability to Embrace Irregular Warfare, Air Command and Staff College, Air University, Alabama, 2014.
} 
savaş dışı harekâtlara olan ihtiyaç, $\mathrm{ABD}$ için belirgin hale gelmekteydi. $\mathrm{Bu}$ doğrultuda küresel bir güç olma iddiasında olan $\mathrm{ABD}$, ordusunu bu dış politikanın bir aracı olarak konvansiyonel harekât dışında da kullanmaya başlayacakt1.

\section{11 Eylül Saldırıları Sonrası Gayrinizami Harbin Yükselişi}

11 Eylül Saldırıları konvansiyonel üstünlüğe dayanarak güvende olduğunu düşünen ABD'nin kendi evinde dokunulmaz olduğu tahayyülüne indirilen travmatik bir darbedir. Güvenliği konvansiyonel bir kavram olarak değerlendiren karar vericilerin, terörün güçsüz olan mütecaviz tarafından bir araç olarak kullanılması fikrine yabancı olmamakla birlikte, sahip oldukları teknolojik üstünlük sebebiyle bu fikri küçümsedikleri görülmektedir. 90'lı yıllarda konvansiyonel yapılanma ve savaş konsepti takip edilerek elde edilen başarıların da etkisiyle ortaya konan Bush Doktrini ve Teröre Karşı Savaş (The War on Terror) olarak nitelendirilen askerî ve politik tutum, başlangıçta başarılı gözükse de önce Afganistan'da ve ardından Irak'ta beklenmedik tepkilerle karşılaştı.

Afganistan'da 8 Ekim 2001 tarihinde başlatılan Sürekli Özgürlük Harekâtı (Operation Enduring Freedom) sonucunda Kasım 2001'de Taliban rejiminin iktidardan uzaklaştırılarak tamamen etkisiz hale getirildiği ilan edildi. Bu kısa süreli harekât sonucunda Taliban önemli kayıplar vermiş olsa da üye ve destekçilerinin büyük bir çoğunluğu Pakistan sınırında bulunan bölgelere kaçabildi ya da Kandahar gibi bölgelerde halkın arasına karışarak varlığını sürdürebildi. ${ }^{7}$ Bu dağınık gruplar, 2004 yılında Molla Ömer liderliğinde bir araya gelerek Neo-Taliban olarak nitelendirilen yeni bir ayaklanma hareketi haline dönüştüler. Bu yeni ayaklanmayla, askerî harekâtın ve politik alanda devam eden devlet inşasının başarısı hakkında çok erken karar verildiği anlaşıldı.

Afganistan'da gelen bu erken başarı $A B D$ ve diğer koalisyon devletlerini Teröre Karşı Savaş kapsamında Irak'a yönelmeye teşvik etti. Teröre Karşı Savaş tutumunun temel felsefesi, yoğun ateş gücü ve kinetik harekâta dayanılarak teröristlerin etkisiz hale getirilmesini ve onlara destek

\footnotetext{
${ }^{7}$ Ahmed Rashid, Descent Into Chaos: The U.S. and the Disaster in Pakistan, Afghanistan, and Central Asia, Penguin Group, US, 2008, p. 240.
} 
veren rejimlerin iktidardan uzaklaştırılmasını öngörmekteydi. ${ }^{8}$ $\mathrm{Bu}$ yaklaşımın egemen olmasındaki en önemli etkenin askerî uzmanlar ve uygulama seviyesindeki askerî personel açısından, GNH kavramının ve elde edilen tecrübelerinin neredeyse unutulma derecesine gelmesi olduğu ifade edilebilir. Bu tarz bir savaşta sürdürülebilirlik, personel mevcudu ve maliyetin ötesinde, ABD halkının tahammül derecesi ile ilintiliydi. Bu bağlamda, belirsiz bir amaç doğrultusunda girilebilecek uzun soluklu mücadelelerin doğuracağı politik risk, Amerikan hükümetlerince alınabilecek seviyede değildi.

ABD önderliğindeki koalisyonun Irak’taki beklentisi, Saddam ve Baas Rejiminin baskıcı yönetim tarzı nedeniyle ülke genelinde halk tarafindan harekâtın destekleneceği yönündeydi. Ne var ki, harekât sonrası gerek Sünni gerekse Şii gruplar tarafindan ABD ve koalisyon güçlerine karşı ayaklanma ve direniş hareketlerine girişildi. Bu süreçte, ateş gücü, modern teknoloji ve stratejiye dayalı bir yaklaşımla başlatılan harekâtlar, konvansiyonel orduların başa çıkmakta zorlandıkları ayaklanma tarzı çatışmalara dönüştü. Irak’ta bu yerel grupların etkinliklerini artırmaları üzerine, mütecaviz/düşman merkezli yaklaşımdan halk merkezli bir savaş/çatışma yaklaşıma ağırlık veren ayaklanmaya karşı koyma (counterinsurgency) kavramına doğru bir yönelim yaşandi. Akademisyen askerler olarak bilinen David Petraeus, John Nagl ve David Kilcullen gibi isimlerin öncülügünde ayaklanmaya karş1 koyma, yaşanmış tecrübeler ve klasik literatür tekrar gözden geçirilerek neo-klasik yaklaşım olarak adlandırılabilecek bir bakış açısı ile yeniden yorumland1. ${ }^{9}$

1 Mayıs 2003 tarihinde USS Abraham Lincoln uçak gemisinde Başkan Bush Irak'taki savaşın sonunu ve koalisyonun zaferini ilan etti. Ancak ülkenin politik ve sosyoekonomik durumu hakkında yeterli bilgiye sahip olamayan ABD önderliğindeki koalisyon, Saddam'ın baskıcı yönetiminin ardından oluşacak otorite boşluğunun ne şekilde doldurulacağını hesaba katamamıştı. Ülkenin Saddam'ın baskısı ile bastırılan etnik ve mezhepsel

\footnotetext{
${ }^{8}$ Colleen Bell, Civilianising warfare: ways of war and peace in modern counterinsurgency, $\mathcal{F}$ Int Relat Dev 14, no. 3 (2011), p. 309.

${ }^{9}$ Colleen Bell, The police power in counterinsurgency: discretion, patrolling and evidence, in War, Police and Assemblages of Intervention, ed. Jan Bachmann, Colleen Bell, and Caroline Holmqvist, Routledge, New York, 2015, p. 17.
} 
kırılımları otorite boşluğu ile su yüzüne çıkarak ülkedeki istikrarsızlığın başlica sebebi haline geldi. Afganistan'da Taliban'la olan ilişkilerde olduğu gibi Irak'taki yeniden yapılanma sürecinde de Baas Partisi üyelerinin kapsam dışı bırakılması, direniş hareketlerinin en önemli meşrulaştırıcısı olarak görülebilir. Irak'taki direniş hareketinin merkezi, başlangıçta Sünni Üçgeni olarak bilinen Bağdat, Fellüce ve Tikrit kentleri çevresinde yoğunlaştı ve akabinde Necef, Kut, Nasiriye ve Basra bölgelerine yayıldı. Baas Partisi eski üyeleri olan güvenlik kuvvetleri personeli bu ayaklanmaların eğitim ve planlama aşamasının en önemli unsuruydu. Buna ek olarak Bush yönetiminin, harekâtının meşruluğunu artırmak maksadıyla Saddam rejimi ile El Kaide arasında bağ kurma çabaları olumsuz bir sonuç doğurdu. ${ }^{10} \mathrm{Bu}$ yaklaşım beklenenin aksine El Kaide ile iltisaklı örgütlerin eğitim, personel ve silah-teçhizat desteği ile ayaklanmanın bir parçası haline gelmelerine yol açtı.

ABD önderliğindeki Irak Çok Uluslu Gücü BM onayı ile 2007 yılına kadar devletin yeniden inşası ve güvenlik kuvvetlerinin eğitim ve donatımı ile ilgili yoğun çabalar sarf etmesine karşın, ülkenin sosyoekonomik durumu hakkında yeterli farkındalığın olmayışı ve net bir politik stratejinin yokluğu nedeniyle istenilen başarıyı sağlayamadı. Ülkede tırmanan şiddet ve artan ayaklanma potansiyeli, askerî birlikleri bu tür faaliyetlerin desteklenmesinden alıkoydu. Ayrica bu konuda uzman sivil personel mevcudunda ve çatışmalara doğrudan girebilecek birlik sayısında da önemli sıkıntılar yaşanmaktaydı.

Diğer taraftan işgal sonrası dönemde Saddam rejimine bağlı eski hükümet ve ordu mensupları ile Sünni ayaklanma hareketlerine odaklanılmış olması ülkede çoğunluğu teşkil eden Şiiler'in göz ardı edilmesine yol açtı. Özellikle 2004 yılı bahar ayları ile Mukteda es-Sadr önderliğindeki Şii ayaklanma hareketi de Necef, Kerbela ve Kut şehirlerini merkez alarak hız kazand1. Sadr, Mehdi Ordusu olarak nitelendirilen silahlı güçleri ile sadece ABD işgaline karşı değil aynı zamanda kurulan Geçici Koalisyon Yönetimine ve Sünni gruplara karşı da mücadeleye girişti. Sünni ve Şii grupların kullandıkları en yaygın taktikler pusu, el yapımı patlayıcı

${ }^{10}$ John K. Cooley, Alliance Against Babylon: The US, Israel and Iraq, Pluto Press, London, 2005, p. 201-02. 
tuzaklamaları, havan saldırıları ve intihar bombacıları olarak sayılabilir. Seyir hallindeki konvoylara karşı yollara tuzaklanan el yapımı patlayıcılar kadar bomba yüklü araç saldırıları da oldukça etkili olmaktaydı. 2004 yılında Sadr tarafından bir ateşkes ilan edilse de 2005 yılı başlarında İran ve Lübnan Hizbullahı'nın da desteği ile tekrar eylemlerine başladı. Eylemlerin hedefinde bazen sadece koalisyon askerleri olurken kimi zaman siviller dâhil olmak üzere yabancı işgalcilerle iş birliği yapan Iraklı hükümet ve ordu yetkilileri de yer almaktaydı. Bu hedef seçiminde mezhepsel farklılıklar da önemli bir unsur olarak görülüyordu.

Irak'ta girişilen harekâtın başarısızlığında politik anlamda rol oynayan en önemli unsur ülkenin ve bölge halkının tam olarak anlaşılamaması ve Batılı paradigma üzerinden anlamlandırılmaya çalışılması olarak görülebilir. Irak'ta Şii çoğunluğa rağmen Sünni azınlı̆̆ın yönetimi elinde bulundurması, geleneği anlamlandırılamayan unsurlara verilebilecek önemli bir örnektir. Saddam rejiminin devrilmesi Sünni halk kitlesi üzerinde travmatik bir rahatsızlık yarattı ve ülke yönetiminin Şiilere ve Sünni Kürtlere geçmesi ayaklanma hareketlerinin temel motivasyonunu oluşturdu. Ülkede Sünni kitle içerisinde de aşiret ve kabile tabanlı bölünmeler bulunmaktaydı. Diğer taraftan ülkede bulunan Şii Araplarla İran Şiiliği arasında da önemli farklılıklar bulunmaktaydı. ${ }^{11}$ Ancak bu karmaşık demografik yapının Batılı bakış açısı ile anlaşılması oldukça güç bir durumdur.

2003-2006 arası dönemde yürütülen ayaklanmaya karşı koyma çabalarının başarısızlığının en etkileyici örneklerinden birisi Felluce'de yaşandı. Bağdat'ın yaklaşık $70 \mathrm{~km}$ batısında yer alan bu kasaba, Saddam Hüseyin'in Nisan 2003'te devrilmesinin ardından ülkenin yönetimini elinde bulunduran Sünni azınlık tarafından ayaklanma hareketinin en önemli merkezlerinden birisi haline getirildi. Mart-Nisan 2004 tarihleri itibariyle Felluce, ABD askerlerine karşı silahlı direniş eylemlerinin büyük ölçüde arttığı bir yerleşim yerine dönüştü. ${ }^{12} \mathrm{ABD}$ askerlerinin Felluce'de baş gösteren ayaklanmaya karşı takındıkları tutum ise klasik ayaklanmaya karşı koyma doktrinini temel aldı. Bu anlamda ayaklanmacılara barınma

\footnotetext{
${ }^{11}$ Faleh A. Jabar, in Tribes and Power: Nationalism and Ethnicity in the Middle East, ed. Faleh A. Jabar and H. Dawod, Saqi, London, 2003.

${ }^{12}$ Cooley, Alliance Against Babylon: The US, Israel and Iraq, p. 213.
} 
sağlayan halk denizinin kalpler ve zihinler politikasıyla kurutulması amaçlanmaktaydı. Ancak yetersiz maddi imkânlar, yerel halk ve yönetimin desteğinin olmayışı ve siyasi irade eksikliği bu politikanın uygulanmasını engelleyen önemli sorunlardı. Bu nedenle ateş gücüne dayalı bir taktik izlendi ve bu durum da ABD karşıtlığını pekiştirdi. ${ }^{13} \mathrm{Bu}$ karşıtlığın en zirve noktası, başarısızlıkla sonuçlanan Birinci Felluce Muharebesi sonrası Blackwater Özel Güvenlik Şirketinin dört çalışanının pusuya düşürülerek vahşice öldürülmeleri ve Firat Nehri üzerinde bir köprüye asılarak sergilenmeleriydi. Bu eylem üzerine şehir Amerikan Deniz Piyadelerince kuşatılarak yoğun ateş gücü ile ele geçirildi. Ancak şehrin neredeyse tamamına yakını yıkılarak sivil halk büyük zarara uğratılmıştı. ${ }^{14}$

ABD yönetiminin Irak'ta düştüğü hatalardan birisi de kitle imha silahlarının bulunduğu iddiasıdır. Yoğun çabalara ve geniş çaplı aramalara rağmen gerek ABD gerekse İngiliz yetkililer tarafından 2004 yılında herhangi bir kanıt bulunamayışı da, var olan ayaklanma hareketlerini desteklediği kadar harekâtın meşruiyetine de zarar vermiştir. ${ }^{15}$ Bir diğer önemli hata ise etkisini giderek artıran ayaklanma hareketleri karşısında takınılan kuvvet yoğun politikanın askerler üzerinde yarattığı etkinin öngörülememesi olmuştur. Uzun süre bu yoğun mücadele içerisinde yıpranan ve ülkenin sosyoekonomik yapısı hakkında bir fikir sahibi olamayan askerlerin gerek sivillere gerekse yakalanan ayaklanmacılara kötü davranışları ayaklanmaya karşı koyma çabalarını olumsuz etkilemiştir. Özellikle Ebu Gureyb Cezaevindeki Amerikan askerlerince yapılan işkence fotoğrafları ve İngiliz askerlerince Basra bölgesinde sivillerin öldürülmesi olayları harekâtın meşruiyeti konusunda olumsuz etkiler yaratmıştır. ${ }^{16}$

2006 yılına gelindiğinde ülke içerisindeki mezhepsel çatışmalar ve ayaklanma hareketleri en üst seviyeye ulaşmış durumdaydı. Şubat 2006'da

\footnotetext{
${ }^{13}$ Patricia Owens, Economy of force: counterinsurgency and the historical rise of the social, Cambridge studies in international relations, Cambridge University Press, Cambridge, 2015, p. 276.

${ }^{14}$ Bing West, No True Glory: A Frontline Account of the Battle for Fallujah, Bantam Books, New York, 2005), p. 3.

15 Joel S. Migdal, Shifting Sands: The United States in the Middle East, New York: Columbia University Press, New York, 2014, p. 239.

16 Rory McCarthy, Amnesty details killing of civilians by British soldiers, The Guardian 2004, https:/www.theguardian.com/world/2004/may/11/military.iraq.
} 
Samarra kentinde bulunan ve Şiilerin en kutsal mekânlarından birisi sayılan Altın Kubbeli Askeriye Camii'nin Sünniler tarafından düzenlenen saldırıda büyük hasar görmesi bu mezhepsel gerginliği en üst seviyeye taşımıştır. Öfkeleri dinmeyen Şiilerce çoğu Sünni olmak üzere 1.300'e yakın kişi öldürülmüş; aralarında sahabe Talha Bin Ubeydullah'ın türbesinin de bulunduğu Sünni camii yakılmıştır. ${ }^{17}$ Artan bu olaylar ABD önderliğindeki ayaklanmaya karşı koyma harekâtının başarısızlığı olarak değerlendirilmekteydi. Büyük çabalarla önemli bölgeler ayaklanma hareketlerinden temizlense de bu bölgelerin elde tutulabilmesi mümkün olmuyordu. 2005 yılı itibariyle sürdürülen mücadelelerin başarı şansı olmadığına dair öngörülerde bulunulmaktayd..$^{18}$ El Kaide Irak lideri olarak görülen Abu Musab al-Zarkavi düzenlenen hava saldırısı ile 9 Haziran 2006'da öldürülse de ABD askerlerini ülkeden çekilmesini ve sorumluluğu Irak hükümetine bırakmasını sağlayacak kadar büyük bir başarı olarak görülmemekteydi.

2003 yılında Irak'a giren ABD ordusu konvansiyonel bir savaşı icra edebilme anlamında gerek teçhizat ve yapılanma gerekse eğitim anlamında en iyi ordulardan birisi olarak görülse de GNH anlamında Vietnam ve Filipinler gibi önemli tecrübelerini unutmuş durumdaydı ya da hatırlamak istemeyen bir kurumsal yapı sergilemekteydi. ${ }^{19}$ Gerek ABD gerekse İngiliz ordusu tarafından sınırlı ölçüde bu tecrübelere yoğunlaşmaya çalışılsa da, 2003 ile 2006 arası dönemde içinde bulundukları durumu ve ülkeyi tam olarak kavrayamamış bir görünüm ortaya koymaktaydılar.

$\mathrm{Bu}$ eksiklik üzerinde durarak $\mathrm{ABD}$ ordusunun ayaklanmaya karşı koyma doktrininin güncellenmesi gerektiğini düşünen General Petraeus kendisi gibi akademisyen subaylardan oluşan bir ekiple geçmiş ayaklanmaya karşı koyma tecrübelerini Irak üzerinden tekrar yorumlama yoluna gitti. ${ }^{20}$ Petraeus Irak'ın işgalinde 101. Hava İndirme Tümen Komutanı olarak

\footnotetext{
${ }^{17}$ Patrick Cockburn, Chaos $\mathcal{E}$ Caliphate, QR Books, New York and London, 2016, p. 130.

18 Thomas E. Ricks, The Gamble: General David Petraeus and the American Military Adventure in Iraq, 2006-2008 Penguin Press, New York, 2009, p. 8.

${ }^{19}$ David H. Ucko, The New Counterinsurgency Era: Transforming the U.S. Military for Modern Wars (Georgetown University Press, Georgetown, 2009, p. 33.

${ }^{20}$ Thomas E. Ricks, The COINdinistas, Foreign Policy, no. 176 (2009), http://wwwjstor-org.openathens-proxy.swan.ac.uk/stable/20684962. (Erişitm Tarihi: 09.06.2020).
} 
Musul bölgesinde görev yapmıs ve bu dönemde halk merkezli bir yaklaşım sergilemişti. Korgeneral olduğunda ise Çok Uluslu Güvenlik Değişimi Komutanlığı görevinde Irak güvenlik güçlerinin yeniden yapılandırılması konusuna yoğunlaşmıştı. Bu tecrübelerini Deniz Piyade Korgeneral James Mattis ile birlikte, Kara Kuvvetleri ve Deniz Piyadeleri için 2006 yılında yayımlanan İsyana Karş1 Koyma Talimnamesi FM 3-24'te doktrin olarak $\mathrm{ABD}$ ordusu yaklaşımlarına kazandırdı.

ABD ordusunda neredeyse Vietnam Savaşından beri var olan doktrin boşluğunu doldurmayı hedefleyen bu talimnameye göre ayaklanmaya karş1 koyma; taarruz, savunma ve istikrar harekâtları gibi farklı türlerin eş zamanlı olarak bir arada kullanımını öngören bir yaklaşımdır. Bu doğrultuda yaklaşım, silahlı çatışmanın yanında kamu kurumlarının, güvenlik kuvvetlerinin, ülkenin altyapısının ve hükümet sisteminin tekrar inşa edilmesini de kapsamalıdır. FM 3-24'ün halk merkezli yaklaşımı konvansiyonel bir yapıya sahip ABD ordusu için önemli bir paradigma değişimi olarak yorumland. Talimname ayaklanma hareketini sadece askerî bir mesele olarak değil, politik, ekonomik ve psikolojik faktörlerin de hâkim olduğu bir kavram olarak yorumlamaktaydı. ${ }^{21}$ Bu bağlamda klasik teorisyenler olan David Galula ve Robert Thompson gibi isimlerin yaklaşımlarının etkisini talimname içerisinde görmek mümkündür.

Talimnameye göre ayaklanmaya karşı koyma harekâtının temel prensipleri; asıl amacının meşruiyeti, yürütülen faaliyetlerin bütünlüğ̈̈, siyasi faktörlerin belirleyiciliği, harekât alanının anlaşılması, hukukun üstünlügüne dayalı bir güvenlik ortamı, bilginin ve beklentilerin yönetimi, ölçülü kuvvet kullanımı ve yerel yönetimin desteklenmesi gibi önemli hususları içermektedir. ${ }^{22} \mathrm{Bu}$ doktrinel değişimin ardından Irak’ta görece bir başarı elde edildiği görülmekle beraber bu başarıda 2008 yılında Bush yönetiminin ülkeden bir an önce çekilmek amacıyla ABD askerilerinin sayısında ve ekonomik kaynaklarda artış sağlama kararının da payı büyüktür.

Bush yönetiminin bu kararı almasındaki en önemli rollerden birisini Petraeus ile yakın ilişkisi bulunan ve 2003 yılında emekli olarak danışmanlık

${ }^{21}$ Sarah Sewall, Crafting a new counterinsurgency doctrine, Foreign Service Fournal (2007).

${ }^{22}$ FM 3-24, Counterinsurgency, Headquarters Department of the Army, Washington, DC, 2006), p. 1-20 - 1-25. 
görevlerinde bulunmaya başlayan General Jack Keane oynadı. ${ }^{23}$ Ocak 2007'de Başkan Bush tarafından açıklanan plana göre sınırlı bir süre için ülkedeki asker sayısını 20.000'den fazla artırılması öngörülmekteydi. Şubat-Haziran 2007 arasında ülkeye gönderilen ABD askeri sayısı 30.000 civarını bularak ülkedeki toplam sayı yaklaşık 170.000'e ulaştı. Yükselen asker sayısı ile birlikte kinetik operasyonlarda da önemli bir artış yaşandı ve 2007 yılı Nisan-Haziran dönemi 331 ABD askerinin ölümü ile 2004'ten beri en fazla zayiat verilen dönem oldu. Ancak gösterilen çaba sonucunda ülkede şiddet oranında ciddi bir düşüş gözlenerek, bu başarı, yeni ayaklanmaya karşı koyma doktrini destekçilerince, kinetik operasyonlar kadar halk merkezli yaklaşımın da bir sonucu olarak duyuruldu. ${ }^{24}$

ABD ordusundaki bu doktrinel değişim sadece FM 3-24'ün yayımlanmasında gözlemlenmemektedir. 2006 yılında ortaya konan Dört Yıllık Savunma Değerlendirmesinde [Quadrennial Defense Review (QDR)] ABD'nin konvansiyonel savaştaki üstünlüğünü kabul eden düşman veya tehdit unsurlarınca gayrinizami harbin (Irregular Warfare - IW) etkin bir yaklaşım olarak tercih edildiği kabul edilmekte ve ABD ordusunun da teşkilat ve doktrin anlamında bu doğrultuda şekillendirilmesi gerektiği vurgulanmaktayd.$^{25}$ Karşı karşıya kalınan bu GNH yaklaşımında mütecaviz ya da tehdit unsurlarının mücadelelerini halkın desteğine ve bu yolla elde edilen meşruiyete dayandırma çabası içerisinde oldukları kabul edilmekteydi. Halkın etkin bir aktör olarak dâhil olduğu bu durum konvansiyonel gücün kullanımına hiç de uygun değildi. Bu tarz bir mücadelenin sadece askerî güç kullanımıyla kazanılamayacağı; bunun ancak siyasi, ekonomik, askerî ve iletişimsel yaklaşımların bir araya getirildiği kapsamlı bir politika ile mümkün olabileceği düşüncesi bu değerlendirmede de net bir şekilde görülmekteydi. ${ }^{26}$

\footnotetext{
${ }^{23}$ Frederick W. Kagan, Choosing Victory A Plan for Success in Iraq, American Enterprise Institute, 2007.

${ }^{24}$ David H. Ucko, Critics gone wild: Counterinsurgency as the root of all evil, Small Wars $\mathcal{E}$ Insurgencies 25, no. 1 (01/02 2014); Stephen Biddle, Jeffrey A. Friedman, and Jacob N. Shapiro, Testing the Surge: Why Did Violence Decline in Iraq in 2007?, International Security 37, no. 1 (2012).

${ }^{25}$ U.S. Department of Defense, Quadrennial Defense Review Report, ed. Department of Defense, Department of Defense, Washington D.C., 2006.

${ }^{26}$ Kenneth C. Jr. Coons and Glenn M. Harned, Irregular Warfare is Warfare, Features,
} 
ABD ordusunun genel yaklaşımında GNH ve bu kavram içerisine giren ayaklanmaya karşı koyma gibi harekâtlar özel birlikler tarafından icra edilmekteydi. Dolayısıyla GNH kavramı bir diğer değişle, özel birlikler tarafından yürütülen harekâtlar olarak nitelendirilmekteydi. Ancak Soğuk Savaş sonrası beliren yeni tehdit algılamasında ABD'nin ve müttefiklerinin karşı karşıya kaldıkları en önemli düşman GNH yaklaşımını benimsemiş devlet dişı yapılanmalar olarak görülüyordu. Doğal olarak konvansiyonel ordu birlikleri ya da QDR içerisinde belirtilen tanımıyla "genel maksat kuvvetleri" bu GNH yaklaşımına ne derece dâhil edilmeli sorusu ciddi bir mesele olarak belirdi. Askerî uzmanlar ve bürokratların netleştirmeleri gereken en önemli konu, yürütülen mücadelelerin GNH olarak nitelendirilmesi ve bu doğrultuda yürütülmesi için görevlendirilen birlikler mi, uygulanan taktik ve yaklaşımlar mi yoksa elde edilmesi beklenen politik amaç mı esas alınmalı sorusuydu. ${ }^{27}$

\subsection{Kavramsal ve Yapısal Anlamda ABD Ordusunda Gayrinizami Harp}

Bu noktada ABD ordusunda GNH kavramının ne anlama geldiğine bir açılklı getirmek gerekmektedir. Türkçeye çevrildiğinde Irregular Warfare (IW) ve Unconventional Warfare (UW) kavramlarının her ikisinin de karşılığ GNH olarak literatüre yerleşmiş durumdadır. Bu iki kavram birbiri ile ilintili olmakla birlikte birbirinin yerine kullanımı önemli bir anlam karmaşasına yol açabilmektedir. IW (Düzensiz/GayriNizami Savaş) olarak kullanılan kavram en geniş anlamıyla düzenli muharebeler dışındaki harekâtları kapsayan genel bir terim olarak kullanılmaktadır. IW şemsiyesi altında, düşman bir devlete karşı girişilen ayaklanma ve direniş hareketlerinin örgütlenmesi ve desteklenmesi anlamında UW (Konvansiyonel Olmayan Savaş), dost ve müttefik devletlere yönelik güvenlik faaliyetlerinin desteklenmesi ve yürütülmesi [Foreign Internal Defense (FID)], ayaklanmaya karş1 koyma harekâtı [Counterinsurgency (COIN)], terörle mücadele [Counterterrorism (CT)] ve istikrar harekâtları (Stability OPs) gibi klasik savaş yaklaşımları dışında kalan harekâtlar bulunmaktadır (Şekil 1). ${ }^{28}$

no. 52 (2009).

${ }^{27}$ Coons and Harned, Irregular Warfare is Warfare.

${ }^{28}$ FP3-05, Special Operations, DoD, Joint Chiefs of Staff, Wasjhington D.C., 2014. 


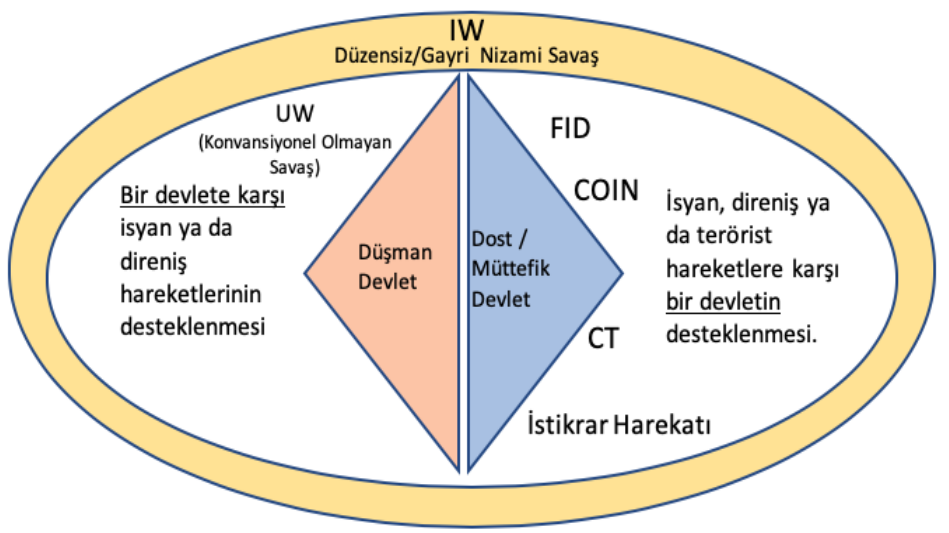

\section{Şekil 1. Gayrinizami Savaş ve Özel Operasyonlar İlişkisii ${ }^{29}$}

Afganistan ve Irak'ta karşı karşıya kalınan ayaklanma hareketleri sadece özel kuvvetlerin faaliyetleri ile başa çıkılabilecek seviyenin oldukça üstündeydi. Bu nedenle GNH konsepti içerisinde değerlendirilen ayaklanmaya karşı koyma doktrininin sadece özel birlikler tarafından değil, alanda görevlendirilen diğer birlikler için de uygulanması gerektiği düşüncesi hâkim olmaya başlamışt1. ${ }^{30} \mathrm{Bu}$ yaklaşım doğrultusunda genel maksat kuvveti olarak tanımlanan özel birlikler dışındaki konvansiyonel birliklerin de uzun soluklu ayaklanmaya karşı koyma harekâtları, eğit-donat faaliyetleri, danışmanlık görevleri, devlet ve güvenlik kuvvetlerinin inşası gibi farklı alanlarda eğitilmesi ve yeniden yapılandırılmaları gerektiği kabul edildi. ${ }^{31}$

ABD askerî terminolojisinde özel harekât, kendine has görevlendirme, taktik, teknik, prosedür ve teçhizat gerektiren özellikli görevleri nitelemektedir. $\mathrm{Bu}$ tür görevler düşman hatlarının gerisinde, konvansiyonel harekât imkân ve kabiliyetinin bulunmadığı ya da politik olarak önemli riskler taşıyan

\footnotetext{
29 "JP3-05, Special Operations, DoD, Joint Chiefs of Staff, Washington D.C., 2014" isimli eserden alınıp yazar tarafından Türkçeye uyarlanmıştır.

${ }^{30}$ David H. Petraeus and James F. Amos, Foreword of FM 3-24 Counterinsurgency, Headquarters Department of the Army, Washington, D.C., 2006.

${ }^{31}$ Coons and Harned, Irregular Warfare is Warfare, p. 99.
} 
coğrafyalarda icra edilmektedir. Diplomatik hassasiyetler doğrultusunda gizli icra edilmeleri, mümkün olduğu kadar az görüntü verilmesinin önemli olduğu ve yerel unsurlarla iş birliği içerisinde hareket etmeyi gerektiren faaliyet türleridir. $\mathrm{Bu}$ anlamda yerel dil ve kültürlere aşinalıktan, ileri derece atış eğitimine, komuta-kontrol yeteneklerinden ayrıntılı koordine becerileri ve disiplin anlayışına kadar kazanılması zor niteliklere ihtiyaç duymaktadır. ABD Ordusunda bu faaliyetlerin yürütülmesinden esas olarak Özel Harekât Kuvvetleri (Special Operations Forces) sorumludur.

Birleşik Devletler Özel Harekât Komutanlığı [United States Special Operations Command (USSOCOM)] müşterek ve birleştirilmiş bir muharip yapı olarak özel birliklerin en üstünde yer almaktadır. Bu yapının altında Saha Özel Harekât Komutanlıkları [Theater Special Operations Command (TSOC)] bulunmakta olup, bu birlikler Savunma Bakanı tarafindan Küresel Kuvvet Yönetimi Uygulama Esasları [Global Force Management Implementation Guidance (GFMIG)] doğrultusunda Bölgesel Muharip Komutanlıklar (Geographic Combatant Commands) emrine verilmektedir. ${ }^{32}$ Bu düzenleme 2011 yılında yayımlanan Özel Operasyonlar Talimnamesinde yapılmış olup, 1998 yllında belirtilen esaslara göre ise özel birlikler sadece askerî birlikler emrine değil büyükelçilikler ya da diğer ilgili kuruluşların kontrolüne de verilebilmekteydi. ${ }^{33}$ Bölgesel Muharip Komutanlıklar, farklı kuvvetler ve özel harekât birliklerinden teşkil edilmiş bir orgeneral emir komutasında bulunan kuvvetleri tanımlamakta olup, Afrika Komutanlığı, Merkez Komutanlığı, Avrupa Komutanlığı, Hint-Pasifik Komutanlığı, Kuzey Komutanlığı ve Güney Komutanlığı olarak altı farklı coğrafyada konuşlandırılmış durumdadır. Saha Özel Harekât Komutanlıkları bu komutanlıklar altında bulunmakla birlikte bir kademe altta teşkil edilen Birleştirilmiş Müşterek Görev Kuvvetleri emrine de görev kuvveti şeklinde özel harekât birliği tahsis edilmektedir. ${ }^{34}$ Örneğin Merkez Komutanlığı bünyesinde ileri karargâhı ile Katar'da bulunan Amerikan Özel Harekât Komutanlığı-Merkez yer almakta, yine Merkez Komutanlığı altında oluşturulan Birleştirilmiş Müşterek Görev

\footnotetext{
32 JP3-05, Special Operations.

${ }^{33}$ JP3-05, Special Operations; JP3-05, Special Operations, DoD, Joint Chiefs of Staff, Washington D.C., 2011.

34 US-DoD, Combatant Commands, (2020). https://www.defense.gov/Our-Story/ Combatant-Commands/. (Erişim Tarihi: 12.08.2020).
} 
Kuvveti-Doğal Kararlılık (Irak/Suriye) altında da Özel Harekât Müşterek Görev Kuvveti-Doğal Kararlılık Harekâtı bulunmaktadır.

Ayrıca yine USSOCOM altında her kuvvet komutanlığı ve deniz piyadelerinin de özel harekât birlikleri teşkil edilmiş durumdadır. $\mathrm{Bu}$ birliklerce icra edilen faaliyetler; doğrudan muharebe görevi, özel keşif faaliyetleri, kitle imha silahlarının önlenmesi, terörle mücadele, konvansiyonel olmayan savaş (unconventional warfare), yabancı ülkelerde iç güvenliğin sağlanması, yerel güvenlik unsurlarının eğitim ve desteği, rehine kurtarma, ayaklanmaya karşı koyma, insani yardım, bilgi destek harekâtı, istihbarat faaliyetleri ile sivil asker iş birliği faaliyetleri gibi oldukça geniş bir alanı kapsamaktadır. ${ }^{35}$ Yine 1998 tarihli talimname incelendiğinde bu belirtilen faaliyetlerde büyük farklılıklar olmadığı göze çarpmaktadır. Vurgulanması gereken önemli bir değişiklik olarak terör ya da ayaklanma hareketleri gibi tehditlerin finans kaynakları ile mücadele konusu da yeni talimnamede özel birliklerce yürütülen GNH faaliyetleri arasında destekleyici bir unsur olarak belirtilmektedir. ${ }^{36}$

11 Eylül Terör Saldırıları sonrası küresel anlamda terör örgütleri, bunlarla ilintili haydut/serseri devletler ya da suç örgütlerinin ABD güvenlik politikalarında en önemli tehdit olarak algılandığının ve GNH yaklaşımlarının ABD ordusunun odaklanması gereken birincil öncelik durumuna geldiğinin bir diğer önemli göstergesi de Savunma Bakanlığı tarafından 2007 yılında yayınlanan GNH Müşterek Harekât Konsepti olarak değerlendirilebilir. ${ }^{37}$ Bu yaklaşıma göre GNH kavramı, sadece özel birlikler tarafından yürütülen bir harekât olmanın ötesinde farklı kuvvetlerin müşterek çabalarının koordinesi ile yürütülen daha genel bir konsept olarak kabul edilmeye başlanmıştır. Bu genel konseptin ortaya konulmasındaki yaklaşım öncelikle konvansiyonel ya da geleneksel savaş kavramı ile içinde bulunan dönemin GNH anlayışı arasındaki farkı netleştirmeye çalışmıştır. Bu iki kavram arasında amacın, stratejik ve politik hedeflere ulaşılması yönünde kuvvet kullanımı olarak değerlendirildiğinde bu bakımdan herhangi bir farklılık

\footnotetext{
${ }^{35} \mathrm{JP3}-05$, Special Operations. 2014.

${ }_{36}$ JP3-05, Special Operations.

${ }_{37}$ Irregular Warfare (IW) Joint Operating Concept (JOC), USA Department of Defense, Washington, 2007.
} 
olmadığ düşünülmektedir. Diğer bir ifade ile klasik savaş tanımında var olan politik hedeflerin elde edilmesi gayrinizami savaş için de geçerlidir. Ancak aktörlerin devlet dışı yapılar olması, yöntemlerin düzenli muharebe dışında terör eylemlerinden siber saldırılara kadar çok geniş bir spektrumda şekillenmesi fark yaratan unsurlar olarak ifade edilmektedir. Diğer önemli farklılık ise politik hedeflere ulaşılmasında doğrudan düşmanın askerî gücünün hedef alınması yerine halk desteğinin kazanılması ve halkın düşüncesinde meşruiyetin sağlanmasının en önemli yöntem olarak görülmesidir (Şekil 2). ${ }^{38}$

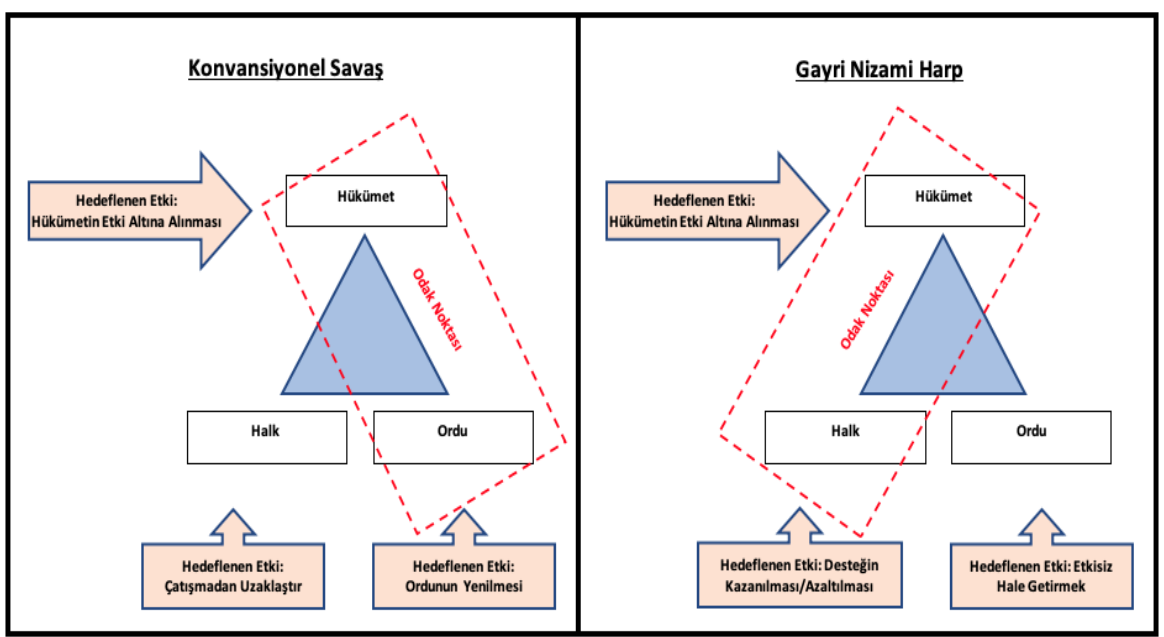

Şekil 2. Konvansiyonel Savaş ve Gayrinizami Harp Ayrımı ${ }^{39}$

Vietnam sonrası ağırlıklı olarak konvansiyonel bir anlayışla yapılandırılan ve yönlendirilen bir ordu için düzensiz, devlet dışı silahlı hareketler karşısında uygulanması gereken operasyonel ve taktik seviyede birtakım hareket tarzlarını oldukça ayrıntılı bir şekilde veren FM 3-24 İsyana Karşı Koyma (FM 3-24 Counterinsurgency) talimnamesinin ayaklanmaya

${ }^{38}$ Irregular Warfare (IW) Joint Operating Concept (JOC).

39 "Irregular Warfare (IW) Joint Operating Concept (JOC), USA Department of Defense, Washington, 2007” isimli eserden alınıp yazar tarafından Türkçeye uyarlanmıştır. 
karşı koyma yaklaşımında öne çıkan önemli prensipler; sivil kayıpların minimuma indirilmesi için kuvvet kullanımının sınırlandırılması, ayaklanmacılarla yerel halk arasında ayrım gözetilmesi, yerel halkın ayaklanmacıların her tür etkisinden korunması, istihbarata dayalı harekât planlamaları, sivil-asker iş birliği faaliyetleri ve hukukun üstünlüğüne dayalı bir güvenlik ortamının yaratılması olarak sıralanabilir. ${ }^{40}$ Her ne kadar bu prensipler konvansiyonel bir ordu için yeni ve devrim niteliğinde bir yaklaşım olarak görülse de aslında daha önce farklı şekillerde elde edilmiş tecrübelerin ve doktrinlerin yeniden hatırlanmasından ibaretti. ABD ordusu içerisinde kısıtlı özel birlikler tarafından yürütülen faaliyetler ve eğitim dokümanları arasında da benzer prensipleri görmek mümkündür.

Irak'ta General Petraeus tarafindan uygulanan yeni ayaklanmaya karş1 koyma doktrinini Afganistan'da uygulama görevi 2009 y1lında General Stanley McChrystal'a verildi. McChrystal'ın ABD Başkanı hakkındaki sert eleştirileri sebebiyle görevinden alınması sonrasında yerine Petraeus getirildi ve Irak'ta gösterilen operasyonel mevzi başarı Afganistan'da da sergilendi. Halk merkezli ve Afganistan'da demokratik ve istikrarlı bir devlet yönetimi kurmaya dayalı mücadelenin başarısındaki en büyük etkenin Taliban'a karşı yürütülen yoğun kinetik harekâtlar olduğu eleştirisine rağmen Petraeus'un yöntemi başarılı olarak değerlendirdi ve Obama yönetimine Afganistan'dan çıkış için bir dayanak noktası sağladı. Ancak bu operasyonel seviyedeki başarının stratejik seviyeye taşınabildiğini söylemek oldukça güçtür. ABD birliklerinin ülkeden çekilmesinden çok, kapsamlı devlet inşası faaliyetleri ve zayiat verilmesine neden olan doğrudan operasyonlara katılımın sona ermesine bir gerekçe olabildi. 2014 sonrasında bu tür görevlerin sorumluluğu Afgan Güvenlik Kuvvetlerine bırakıldı.

Afganistan'daki duruma daha yakından bakılacak olursa; 11 Eylül Saldırıları sonrasında az sayıda özel birlikler kullanılarak eski Mücahitler ve savaş ağalarının yönlendirilmesi ve hava üstünlüğü ile kısa süre içerisinde Taliban yönetimi ve taraftarları ülkeden uzaklaştırıldı. Eski Mücahitlerle yapılan ortaklık, zaten Taliban'ın da ortaya çıkmasına zemin hazırlayan güç mücadelelerini farklı bir şekilde geri getirdi. Bu savaş ağaları, yeni

\footnotetext{
${ }^{40}$ Ryan Evans, COIN is dead, long live the COIN, Foreign Policy 2020, https://foreign policy.com/2011/12/16/coin-is-dead-long-live-the-coin/ (Erişim Tarihi: 26.09.2020).
} 
kurulan devlet ve güvenlik yapılanması içerisinde birtakım makamlar verilerek resmileştirilmeye ve yeni sisteme entegre edilmeye çalışılsalar da ellerindeki gücü bırakmaları sağlanamadı. Bunun birinci nedeni elde ettikleri gücün etkisiyse ikinci nedeni de Taliban tehdidi ve birbirlerine yönelik husumetlerinin ortadan kalkmamıs olmasıdır. Bu durum yine özellikle ülkenin güney kesimleri başta olmak üzere halkta istismara açık hoşnutsuzluklar yarattı. Yeniden inşa edilmeye çalışılan devlet içerisinde bu sorunlarla uğraşılırken, Taliban hareketi tamamen yok sayıldı ve hiçbir şekilde yeni sistem içerisine entegre edilmesi düşünülmedi. Baas Rejimi'nin Irak'ta göz ardı edilmesinin yol açtığı sonuçların benzerleri Afganistan'da da yaşand1. Pakistan-Afganistan arasında kalan kontrolsüz bölgeler Taliban'a korunma alanı sağladığı kadar yeniden yapılanmasına ve gelişen duruma göre yeni stratejiler belirlemesine imkân sundu.

İlk ortaya çııışında nispeten muadili yapılara karşı bir mücadele yürüten Taliban hareketi, ABD önderliğindeki koalisyona ve NATO kuvvetlerine karşı tam bir asimetrik savaş ve gerilla tarzı bir mücadeleye girişti. Daha önce ülke içerisinde farklı gruplara karşı yönetimi ele geçirme şeklinde beliren mücadele artık ülkelerini işgal eden gayri-Müslim bir koalisyona karşı verilen bağımsızlık mücadelesi kisvesine büründü. Bu anlamda mücadelelerini, artık sadece kendi ülkelerini değil küresel anlamda İslam'ın düşmanı olarak gördükleri kâfirlere karşı girişilen kutsal bir savaş olarak nitelendirmeye başladılar. ${ }^{41}$ Ülkelerini hem savaş ağalarının zulmünden hem de yabancı işgalinden kurtararak İslami bir sistem kurma hedefi politik anlamda taraftar toplamak açısından daha tutarlı bir hedef haline geldi. ${ }^{42}$ Sadece politik anlamda değil aynı zamanda rüşvet, yolsuzluk ve din düşmanı yabancılarla iş birliği yaptıkları gibi hususlara vurgu yaparak kurulan yeni hükümeti halkın nazarında ahlaki anlamda da itibarsızlaştırmaya çalıştılar. Dolayısıyla, yeni hareketin geçmişte olduğundan daha fazla iletişim araçları ve propaganda

${ }^{41}$ Theo Farrell and Antonio Giustozzi, The Taliban at war: inside the Helmand insurgency, 2004-2012, International Affairs 89, no. 4 2013: p. 853; Amin Tarzi, The Neo-Taliban, in The Taliban and the Crisis of Afghanistan, ed. Robert D. Crews and Amin Tarzi, Harvard Univerity Press, USA, 2008, p. 275-76.

${ }^{42}$ Alia Brahimi, The Taliban's Evolving Ideology, LSE Global Governance, London, 2010, http://www.lse.ac.uk/globalGovernance/publications/workingPapers/WP022010.pdf, (Erişim Tarihi: 14.07.2020); Michael Semple, Rhetoric, Ideology, and Organizational Structure of the Taliban Movement, United States Institute of Peace (Washington, D. C., 2014). 
yöntemlerini kullanarak ayaklanmayı farklı boyutlara taşıması da fark yaratan bir özellik olarak görülebilir.

Yeni Taliban hareketinin bir diğer özelliği de ülke yönetimine talip olması ve bunu da ele geçirdiği bölgelerde sergilediği yönetimle kanıtlamaya çalışmasıdır. ${ }^{43}$ Gölge yönetim olarak ifade edilen bu yapılar Mao'nun Çin'de göstermiş olduğu mücadeleye benzer bir şekilde ülkenin tüm bölgelerinde kurulmuş olup ele geçirilen yerlerde doğrudan uygulamaya konulmaktadır. Bir anlamda sadece safi şiddet ve silahlı mücadele değil aynı zamanda idari ve sosyoekonomik uygulamalarla halkın kalp ve zihinlerini de hedef almaktadırlar. Merkezi yönetimin ülke genelinde hâkimiyet sağlayamaması ve devlet görevlilerinin istismarları sonucunda özellikle uzak yerleşim alanlarında Taliban, sunduğu adalet ve güvenlik gibi hizmetlerle halk gözünde meşruiyet kazanabilmektedir. ${ }^{44}$

ABD önderliğinde NATO koalisyonunun Taliban ayaklanmasına karşı geliştirdiği yöntem halkın kalp ve zihinlerine odaklanılması gerektiğini savunmakta ve ülkenin yeniden yapılandırılması ve yeni hükümetin demokratik rejim ve serbest piyasa ekonomisi temelinde meşruiyetinin ve hâkimiyetinin artırılmasını ön görmekteydi. Öncelikle sadece büyük şehirlere ve Kabil'e bağlı kalan güvenlik ve devlet otoritesinin, kırsal kesimlere de götürülmesine yönelik çareler arandı. Kuvvet kullanımına dayanarak Taliban'ın etkisiz hale getirilmesine müteakip, yerelde mülki idare siteminin kurulması ve kalkınmanın desteklenmesine yönelik proje ve uygulamalar geliştirilmeye çalışıldı. Bu şekilde Taliban'la sadece askerî alanda değil aynı zamanda ülkenin yönetimine talip olma anlamında politik alanda da mücadele etmek amaçlandı. Bölgesel İmar Timleri [Provincial Reconstruction Team (PRT)], Köy İstikrar Harekâtları [Village Stability Operations (VSO)] ve Afgan Yerel Polisi [Afghan Local Police $(A L P)]$ bu uygulamalardan en önemlileridir.

Ayrıca Afgan Güvenlik Kuvvetlerinin kendi kendilerine yetebilecek seviyeye ulaştırılmaları da önemli bir hedef olarak ortaya konuldu. Bir

\footnotetext{
${ }^{43}$ Antonio Giustozzi, Koran, kalashnikov and laptop: the neo-Taliban insurgency in Afghanistan, Hurst \& Company, London, 2007, p. 99.

${ }_{44}$ David Kilcullen, Out of the mountains: the coming age of the urban guerrilla, Oxford University Press, (Oxford; New York, 2013), p. 144-45; Giustozzi, Koran, kalashnikov and laptop, p. 111.
} 
taraftan ülkenin sosyoekonomik ve politik istikrarının sağlanmasına yönelik sivil çabalar devam ederken diğer taraftan da güvenlik kuvvetlerinin eğitimine ağırlık verilmesindeki en önemli amaç, özellikle 2009 sonrasında ayaklanmaya karş1 mücadeleyi Afgan otoritelerine devrederek ülkeden ayrılmaktı. 2014 yılı itibariyle bu amaca ulaşıldığı kabul edilerek NATO Afganistan'daki doğrudan çatışmalarda yer alma sürecinin ISAF ile birlikte sona erdiğini ilan etti ve sorumluluğu sadece eğitim ve danışmanlıkla sınırlandırılan Kararlı Destek (Resolute Support) Harekâtına geçildi.

Benzer şekilde Irak'ta da istatistiki anlamda ve algı yönetimi ile elde edildiği düşünülen başarı sonucunda Irak hükümeti ile Kasım 2008'de varılan antlaşmaya göre ABD birlikleri 2009 yılı ortalarına kadar kırsaldaki şehirlerden, 31 Aralık 2011 tarihine kadar da ülkeden ayrılması planlanmış ve Bush'un ardindan yönetime gelen Obama döneminde de bu plana büyük ölçüde uyularak 2011 sonunda $\mathrm{ABD}$ bütün yetki ve sorumluluğu Irak hükümetine bırakarak ülkeden çekilmiştir. Ancak, Irak'ta etkinleştirilmeye çalışılan ekonomik ve politik durum hiçbir zaman ülkenin tamamına hâkim olmayı başaramamıştır. Bugün Irak'ta yaşanan sorunlar, etnik ve mezhepsel problemler yüzünden meşruiyet sorunu yaşayan Irak hükümetinin üstesinden gelebileceğinin çok ötesindedir.

\subsection{Politika Yoğun Bir Mücadele Olarak Gayrinizami Harp}

Ortaya konan yeni ayaklanmaya karşı koyma doktrinini, klasik öğretideki politik mücadeleyi kinetik operasyonlardan daha önemli gören halk merkezli yaklaşımın değişen çağa uyarlanmış bir hali olarak görmek mümkündür. Bu yaklaşımda ayaklanma hareketinin temel yaşam kaynağı ve hedefi olan halkın kazanılmasına yönelik ekonomik, politik ve toplumsal yaklaşımlar geliştirmek mücadelenin kazanılmasının anahtarı olarak görülmektedir. Savaşın kazanılması için politikanın bir araç olarak kullanılması anlamına gelen bu yaklaşım, devlet otoritesinin tesis edilerek halkın ihtiyaç ve isteklerinin karşılandığ 1 bir ortam yaratmayı amaçlamaktadır. Afganistan'da devlet otoritesinin tesisi ve kalkınmanın imkânlı kılınması yönündeki ilk çabalar, ISAF'ın kontrol alanını Kabil dışındaki bölgelere yaygınlaştırmak adına kurulan Bölgesel İmar Timleridir. 2003 yılında ülkenin Kuzeyinde bulunan Kunduz şehrinde başlayan PRT programı saat yönünün tersi istikamette ülke geneline yaygınlaştırıldı. PRT'lerin görevi kuruldukları bölgelerde ekonomik kalkınma sağlamak, güvenliği artırmak ve yerel yönetimin otoritesini desteklemekti. Bu amaçla 
sivil ve askerî uzmanlardan oluşan karma bir yapı olarak tasarlanmışlardı. Ancak 2005 yılı itibariyle yeniden örgütlenen Taliban'ın saldırılarını artırması, NATO'nun şiddet yoğun bir ayaklanmaya karşı koyma harekâtının içine çekilmesine neden oldu.

$\mathrm{Bu}$ dönemde ISAF komutanı olan İngiliz General David J.Richards, İngiliz ayaklanmaya karşı koyma tecrübeleri ışığında NATO'nun sıcak çatışma görevleri ile politik görevlerini aynı anda icra edecek bir politika izlemesi gerekliliğine dayalı bir anlayışı benimsedi. Bu yaklaşım İngilizlerin Malaya'da uyguladıkları ve başarılı kabul edilen ayaklanmaya karşı koyma yaklaşımı ile oldukça uyumluydu. ${ }^{45}$ Richards'ın bu stratejisi Fransız General Lyautey'un Gallieni'den uyarlayarak Fas'ta uyguladığı “yağ lekesi” yöntemine benzemektedir. $\mathrm{Bu}$ yöneteme göre ayaklanmaciların hâkimiyetinden kurtarılan bölgelerde sosyal ve ekonomik kalkınmanın sağlanmasına yönelik eğitim ve sağlık kurumları, pazar yerleri gibi yapılar inşa ederek ayaklanmanın sona erdirilmesine ve eski ayaklanmacıların da topluma kazandırılmasına çalışılmaktadır. ${ }^{46} \mathrm{Bu}$ çabaların ayaklanma harekelerinin görüldüğü bölgelerde bir yağ lekesi gibi başlatılarak tüm ülkeye yayılması amaçlanmıştı. Layaute'in bu yaklaşımı David Galula ve akabinde David Petraeus'un başını çektiği yeni ayaklanmaya karşı koyma teorisyenlerini derinden etkilemişti. Richards'ın bu klasik ayaklanmaya karşı koyma politikaları kendisinden sonra gelen Amerikan generallerince de uygulanmaya çalışıldı. Örneğin, General Mckiernan Afgan hükümetinin desteklenmesi için öncelikle ayaklanmanın yenilgiye uğratılması ve güvenli bir ortam sağlanması gerektiği akabinde sürdürülebilir ve başarılı bir hükümet yapısının ülke geneline hâkim kılınması ve kalkınmanın desteklenmesi gerektiğini savunmaktaydı. Bu yaklaşımda Malaya'da Robert Thompson tarafindan uygulanan klasik temizle, elde tut ve inşa et (Clear, Hold and Build)yaklaşımı net bir şekilde görülmektedir. ${ }^{47}$

Afganistan'da izlenen taktik ve stratejilerde önemli değişiklikler

\footnotetext{
${ }^{45}$ David Julian Richards, Commander's Foreword, ISAF Mirror, no. 30 July 2006, p. 3.

${ }^{46}$ Andrew F Krepinevich, How to win in Iraq, Foreign Affairs 85, No.5, no. September/ October 2005, http://www.foreignaffairs.com/articles/61024/andrew-f-krepinevich-jr/howto-win-in-iraq, (Erişim Tarihi: 16.08.2020).

${ }^{47}$ John A. Nagl, ISAF Campaign Plan Summary, Small Wars fournal, November 19, 2008. http://smallwarsjournal.com/blog/isaf-campaign-plan-summary. (Erişim Tarihi: 18.09.2020).
} 
meydana gelmesinde Irak'ta elde edilen başarı kadar Obama hükümetinin yönetime gelişinin de etkisi oldu. Başkan Obama'nın seçimlerde Afganistan'dan Amerikan askerlerini en kısa zamanda çekme vaadinin gerçekleşmesi için ihtiyaç duyduğu acil başarının yolu olarak General McChrystal ve Irak'ta geliştirilen yeni ayaklanmaya karşı koyma doktrini görüldü. ${ }^{48} \mathrm{Bu}$ yeni yaklaşımın ilk uygulaması emir-komuta yapısının değiştirilmesi olmuştur. 1952 yılında General Sir Gerald Templer'in hem askerî hem de politik yetkilerle donatılarak Malaya'daki karşı ayaklanma harekâtının başına getirilmesinde olduğu gibi McChrystal da hem NATO hem de ABD birliklerinin komutanı olarak atanarak ayaklanmaya karşı koyma harekâtının tek elden yürütülmesi sağlandı. Diğer taraftan McChrystal'ın altında korgeneral seviyesinde ISAF Müşterek Komutanlık (IJC) makamı teşkil edilerek ISAF Komutanı stratejik ve politik konularla sorumlu k1lınarak hareket serbestisi kazandırıldı. Bu sayede GNH ve ayaklanmaya karş1 koyma faaliyetlerinin taktik, operatif ve stratejik seviyede daha ayrıntılı ve sağlıklı bir şekilde planlanarak yürütülebileceği düşünüldü. ${ }^{49}$

Diğer bir önemli değişim olarak; İçişleri ve Savunma Bakanlıklarını da kapsayacak şekilde polis ve ordunun yeniden yapılandırılması ve eğitilmesi maksadıyla NATO Afganistan Eğitim Görevi teşkil edildi. Bu yapısal değişikliklere ek olarak ISAF emir komuta yapısına eklenen tugay seviyesinde özel operasyon birliği, bu yeni halk merkezli mücadelenin önceki dönemlere göre daha agresif bir hal alacağının işareti olarak değerlendirilmekteydi. Bu yeni strateji, kinetik ve kinetik olmayan çabaların bir bileşimi olarak tasarlandı.

General McChrystal özel kuvvetler komutanı olarak, Irak'ta General Petraeus komutasında yürütülen halk merkezli ayaklanmaya karşı koyma harekâtının silahlı mücadele boyutunda yer almıştı. ${ }^{50} \mathrm{Bu}$ nedenle hem

${ }^{48}$ Peter Beaumont, Stanley McChrystal: The president's stealth fighter, The Guardian, 26.09.2009, http://www.theguardian.com/theobserver/2009/sep/27/stanley-mcchrystalcommander-us-forces. (Erişim Tarihi: 18.09.2020).

49 Emrah Özdemir, Post-Conflict Statebuilding as a Counterinsurgency Strategy: A Critical Analysis of Afghanistan, Yayımlanmamıs Doktora Tezi, Swansea University College of Art and Humanities, Swansea, 2016, p. 117-118.

50 Sten Rynning, NATO in Afghanistan: The Liberal Disconnect, Stanford Security 
doğrudan operasyonlar icra etme gibi kinetik boyuta hem de halk merkezli yaklaşıma hâkim olabilmekteydi. McChrystal'ın Afganistan'da özel kuvvetleri etkin bir şekilde kullanmasının bir diğer örneği Köy İstikrar Harekâtları olmuştur. Bu harekâtlarda on iki kişilik özel kuvvet timlerinin Afgan yerleşim yerlerinde halkla iç içe yaşayarak yerel polis ve korucu unsurlarının eğitimini ve yerleşim alanlarının güvenliğini sağlayabilmeleri amaçlanmıştı. Kritik küçük yerleşim alanlarında sağlanan güvenlik daha sonra yaygınlaştırılarak tüm ülkeyi kapsayabileceği fikrine dayanmaktaydı. Afgan Yerel Polisi de benzer bir yaklaşımla yerel unsurların meşru bir şekilde ayaklanmaya karşı koyma harekâtında kullanılmasını öngören pragmatik bir yöntem olarak düşünülmüştü. ${ }^{51}$

McChrsytal, halk merkezli yaklaşıma eklediği yoğun kinetik operasyonlarla Taliban karşısında önemli bir başarı elde etti. Kinetik ve kinetik olmayan operasyonların bir bileşimi olan bu yaklaşımın ilk uygulaması Taliban'ın en güçlü olduğu Güneydeki Helmand'da gerçekleştirildi. Helmand bölgesindeki en kritik yerlerden birisi olan Marjah'a yapılan operasyon neticesinde Taliban bölgeden uzaklaştırılarak yeniden yapılandırma faaliyetlerine girişildi. Marjah McChrystal'ın uygulamaya koyduğu yaklaşımının bir prototipi olarak değerlendirilmekteydi. ${ }^{52}$ Ancak McChrystal, kendisi ve ekibinin Başkan Obama ve politikaları hakkındaki eleştirilerin Rolling Stones Dergisinde yayınlanması ile kariyerine erken veda etmek zorunda kald1.

McChrystal'dan boşalan ISAF komutanlığına yeni ayaklanmaya karşı koyma doktrinin baş aktörü olan Petraeus getirildi. Petraeus emir komuta kabiliyeti ve askerî becerilerinden ziyade politik beklentilere cevap verebilmeyi ön plana alan bir strateji ile Obama hükümetinin ülkeden çekilebilmesine imkân tanıyacak ölçüde başarı ve olumlu tablo ortaya koymayı hedefledi. ${ }^{53}$ Ancak bu yaklaşımı esnasında McChrystal'ın yerel

Studies, Palo Alto, 2012, p. 188.

${ }^{51}$ Joe Quinn and Mario A. Fumerton, Counterinsurgency from Below: The Afghan Local Police in Theoretical and Comparative Perspective, COIN Advisory and Assistance Team of ISAF, Kabul, 2010.

${ }^{52}$ Stanley A. McChrystal, My share of the task: a memoir, Portfolio/Penguin, New York, 2013, p. 326.

${ }^{53}$ Özdemir, Post-conflict Statebuilding, p. 123. 
yapılara göstermiş olduğu ilgi ve önemi Petraeus'un gösterdiği söylenemez. Bu dönemde daha çok kinetik operasyonlara ağırlık verilerek etkisiz hale getirilen Taliban militanları başarı olarak değerlendirildi. Gerek McChrystal gerekse Petraeus'un uyguladıkları stratejinin kısmen başarı sağlamış olduğu kabul edilse bile bu başarının sürdürülebilirliği hakkında önemli soru işaretleri bulunmaktaydı. 2014 yılında tüm sorumluluğun devredildiği Afgan hükümeti ve ordusunun Taliban'la başa çıkabilecek kapasite ve yetenekte olduğunun gerçek diş1lığı açıkça görülmekteydi. ${ }^{54}$

\section{3. İsyana Karşı Koyma Yaklaşımında Köklü Değişim}

Irak ve Afganistan'da GNH bağlamında yürütülen halk merkezli ayaklanmaya karşı koyma harekâtları kısa vadede istatistiki olarak istenen başarıyı göstermişti. $\mathrm{Bu}$ durum $\mathrm{ABD}$ hükümetinin Afganistan'dan çekilebilmesi için ihtiyaç duyduğu meşru ve kabul edilebilir gerekçeyi oluşturdu. Ancak bu kısa vadeli başarı tablosunun ardında sürdürülebilir bir istikrar ortamı bulunmamaktaydı. İsyana karşı koyma harekâtının ekonomik, politik ve toplumsal boyutunu oluşturan demokratik ve meşru bir hükümetin teşkil edilerek kabul görmesi, güvenlik ortamının sağlanması, ekonomik kalkınma için gerekli yatırımlar, işlerlik kazandırılmış serbest piyasa ve adil bir hukuk sistemi gibi gereklilikler iki ülke için de sağlanamamıştı. En önemlisi ülkedeki barış ve istikrar ortamını garanti altına alabilmek için en önemli gereklilik olan güvenlik kuvvetleri imkân ve kabiliyet açısından yeterli seviyede değildi. Bu kapsamlı çabaların yetersizliklerine rağmen getirdikleri maliyet, beklenenin çok üstündeydi. Her ne kadar her iki ülkede de kinetik operasyonlarda doğrudan yer almama kararıyla birlikte verilen kayıplarda önemli bir düşüş sağlansa da neredeyse yirmi yıla yakın bir süredir devam eden bir mücadeleyi ekonomik ve insan kaynağı anlamında sürdürmeye gerek politik ortamın gerekse ABD halkının tahammülü kalmamıştı.

$\mathrm{Bu}$ nedenle halk merkezli ayaklanmaya karşı koyma yaklaşımı kazandığı popülerliği yaratıcılarının profesyonel kariyerleri ile birlikte kaybetmeye başladı. Irak ve Afganistan'daki askerî varlık, danışmanlık ve

\footnotetext{
${ }^{54}$ John F. Sopko, Why ANSF Numbers Matter: Inaccurate and Unreliable Data, and Limited Oversight of On-Budget Assistance Put Millions of U.S. Taxpayer Dollars at Risk, SIGAR, Virginia, Apr 29, 2015.
} 
eğitim faaliyetlerinin yürütülmesi, hava desteğinin sağlanması ve kısıtlı doğrudan operasyonların gerçekleştirilebilmesi için gerekli olan az sayıda personel bulundurulmasına indirildi. Muharip birlik olarak özel harekât kuvvetleri ve yakın hava desteği sağlayabilecek hava unsurları bırakıldı. $\mathrm{Bu}$ değişimin hazırlanan raporlara Beyaz Saray nezdinde de ayaklanmaya karşı koyma ile terörle mücadele arasında yapılması gereken bir seçim olarak yansıdığı görülmekteydi. İki yaklaşımdan ayaklanmaya karşı koyma, halk desteğinin kazanılmasına yönelik geniş kapsamlı uygulamaları, sivil asker iş birliği faaliyetlerini ve bunlar için yeterli çapta birlikleri gerekli kılmaktaydı. Terörle mücadele yaklaşımı ise büyük çapta birliklerin ve geniş kapsamlı uygulamaların faydalı olmaktan öte durumu daha da olumsuz hale getirdiğini belirtmekteydi. Bunun yerine küçük çaplı -tercihen özel birliklerle- kuvvetlerle istihbarata dayalı harekâtlar icra ederek terör örgütlerinin ağları ve lider kadrolarını hedef almanın daha etkin olacağı değerlendirilmekteydi. ${ }^{55} \mathrm{Bu}$ yaklaşımın en güncel örnekleri Suriye ve Irak'ta görmek mümkündür.

Irak'ta ülkedeki iç karışıklıkların ötesinde 2014 yılı itibariyle oldukça etkin bir aşamaya gelen DAEŞ terör örgütüne karşı icra edilen harekâtlarda bu yaklaşım kullanılmıştır. Suriye'de de yine 2011 sonrası ortaya çıkan iç karışıklıktan faydalanan DAEŞ'e karşı YPG/PYD terör örgütünü de kapsayan SDF'nin eğitim, lojistik ve silah desteği ile kullanıldığ görülmektedir. Bu tür yerel unsurlara sadece silah ve teçhizat desteği sağlanmamakta aynı zamanda ateş desteği de mevcut ateş destek vasıtaları olan top ve uçaklar vasıtasıyla sağlanmaktadır. Bu desteği sağlamakla görevli en önemli unsur Birleştirilmiş Müşterek Görev Kuvveti-Doğal Kararlılık (Irak/Suriye) ve onun altında bulunan Özel Harekât Müşterek Görev Kuvveti-Doğal Kararlılık Harekâtı'dır.

$\mathrm{Bu}$ tartışmanın en olumsuz yanı ise terör örgütlerinin bulunduğu alan ile ayaklanmaya karşı koyma yaklaşımının uygulandığı alan arasındaki farklılıkların göz ardı edilmiş olmasıdır. Örneğin, Afganistan'da Taliban hareketinin temel dinamikleri ile DAEŞ ya da Irak'taki etkin çatışmaların

${ }^{55}$ Lawrence E. Cline, COINdinistas versus Whack-a-Mole: The Debate on COIN Approaches, in The Future of Counterinsurgency, ed. Lawrence E. Cline and Paul Shemella, Praeger, California, 2015. 
dinamikleri arasında önemli farklılıklar bulunmaktadır. Bu nedenle terör yapılanmalarının sadece özel birliklerle ve kinetik operasyonlarla hedef alınmasının GNH uygulayan mütecavize karşı etkili olacağını değerlendirmek önemli bir hatadır. Ekonomi ve insan kaynağı anlamında daha az riskli olan bu yöntemin seçilmesindeki en önemli etken politik kaygılar olarak değerlendirilebilir. Örneğin 2012 yılında Beyaz Saray tarafından yayımlanan Savunma Bakanlığı Stratejik Planlama Esasları'nda ABD'nin Afganistan'daki hedefinin El Kaide'nin ülkedeki yapılanmasına indirgendiği ve küresel anlamda terörle mücadelenin sadece doğrudan kısıtlı operasyonel faaliyetlerle ve yerel güvenlik kuvvetlerinin eğitim ve desteklenmesiyle sınırlandırıldığı görülmektedir. Yine aynı esaslar içerisinde ABD ordusunun Irak ve Afganistan'da uzun süredir uygulanan kapsamlı ayaklanmaya karşı koyma faaliyetlerinde artık yer almayacağ belirtilmektedir. $^{56}$

Klasik halk merkezli kalpler ve zihinler yönteminin yeniden uyarlaması olarak görülen ayaklanmaya karşı koyma yaklaşımının zaman, maddi kaynak ve insan gücü bakımından sürdürülebilir olmadığ 1 düşünülerek bu tür harekâtlara doğrudan katılım sağlama konusunda tereddütler 2014 yılında yenilenen İsyana Karşı Koyma Talimnamesinde de görülmektedir. $\mathrm{Bu}$ talimnamede $\mathrm{ABD}$ ordusunun ayaklanma hareketleri karşısında doğrudan müdahil olmak yerine yerel hükümet ve güvenlik kuvvetlerinin desteklenmesi yoluyla politik amaçlara ulaşma yönünde bir tercih yaptığı yorumu yapılabilir. 2016 yılında yayımlanan versiyonda sosyal antropoloji, yeniden yapılanma, devlet inşası gibi kapsamlı çabalar yerine daha çok güvenlik kuvvetlerinin imkân ve kabiliyetlerinin artırılmasına ve bu yolla kinetik operasyonel faaliyetlerin yerel kuvvetlerle sağlanması vurgulanmaktadır. Bölgenin hassasiyetlerinin anlaşılması ve halk desteğinin kazanılması gibi temel prensipler korunmakla birlikte muharebeye dayalı faaliyetler yerine dolaylı müdahale olarak nitelendirilen güvenlik kuvvetlerinin desteklenmesi gerektiği belirtilmektedir. ${ }^{57}$

\footnotetext{
${ }^{56}$ The White House, Sustaining U.S. Global Leadership: Priorities for 21st Century Defense, Department of Defense, Washington, D.C., 2012.

${ }^{57}$ FM 3-24, Insurgencies and Countering Insurgencies, Headquarters Department of the Army, Washington D.C., 2014.
} 
GNH yaklaşımları arasındaki bu değişimin bir diğer önemli nedeni ise Rusya Federasyonu, İran, Çin ve Kuzey Kore gibi ülkelerin daha önemli birer tehdit olarak algılanmaya başlamasıdır. Özellikle 2011 sonrası dönemde bu ülkelerle $\mathrm{ABD}$ ve müttefiklerinin ekonomik, politik ve askerî çıkarları Ukrayna, Baltık Denizi, Güney Çin denizi, Orta Doğu ve Afrika gibi alanlarda çatışmaya başladı. Bu çatışma doğrudan olmasa da mevcut yerel unsurların desteklenmesi şeklinde kendini göstermektedir. ${ }^{58}$ ABD'nin yaklaşımındaki bu değişimde tehdit olarak algıladığı bu ülkelerin politikalarının da önemli etkisi oldu. Rusya Federasyonu'nun 2014 yılında Kırım'ı ilhakı ve Doğu Ukrayna bölgesinde yaşanan çatışmalar literatürde hibrit savaş kavramının popüler hale gelmesine neden oldu.

Hibrit savaş, genel anlamıla politik amaçlar doğrultusunda konvansiyonel birliklerin kullanımıyla aynı anda GNH yöntemleri, suç ve terör yapılanmalarına, ekonomik yaptırımlara ve siber sistemlere dayalı yöntemlerin bir arada uygulandığı geniş kapsamlı bir doktrini kastetmektedir. $^{59}$ Yine 2008 yllında Gürcistan'a düzenlenen askerî müdahalede de Rusya düzenli ordu birlikleri, yerel silahlı gruplar ve özel kuvvetler gibi farklı yapılanmaları tek bir politik amaç çerçevesinde kullandı. Bir diğer örnek ise İran'ın Orta Doğu'da İsrail'in üstünlüğüne karş1 Hizbullah'ı desteklemesi, Devrim Muhafızlarına bağlı özel kuvvet niteliğindeki Kudüs Gücü üzerinden Orta Doğu ve Kuzey Afrika'da etkinlik göstermesi verilebilir. Bu anlamda, Irak'ta ve Suriye'de ABD'nin 1990 Körfez Savaşı sonrasından bu yana bölgedeki Kürt yapılanmalarını ebedi müttefik olarak görmek suretiyle DAEŞ’e karşı eğitim, lojistik ve planlama anlamında SDF'nin desteklemesi de ABD ordusu ve Dişişleri Bakanlığı tarafından yürütülen farklı bir hibrit savaş olarak değerlendirilebilir. Yine Irak'ta Kudüs Gücü Komutanı İranlı General Kasım Süleymani’nin öldürülmesi de ABD güvenlik stratejileri doğrultusunda İran'la yürütülen hibrit savaşın bir kanıtıdır. ${ }^{60}$ Yemen ve Libya'da da farklı tarafların doğrudan ya

\footnotetext{
${ }^{58}$ David Kilcullen, The Evolution of Unconventional Warfare, Scandinavian Fournal of Military Studies 2, no. 1, 2019.

59 Peter R. Mansoor, Introduction: Hybrid Warfare in History, in Hybrid Warfare: Fighting Complex Opponents from the Ancient World to the Present, ed. Williamson Murray and Peter R. Mansoor, Cambridge University Press, Cambridge, 2012.

${ }^{60}$ Wilson Dizard, Who will win a 'hybrid war' between the US and Iran?, TRT World
} 
da dolaylı olarak desteklenmesi de bu yeni savaş yaklaşımının örnekleridir.

ABD Ordusunun 2035 yılında sahip olması gereken imkân ve kabiliyetlere yönelik yapılan bir çalışma olan 2019 Ordu Modernizasyon Stratejisi isimli raporda da ABD'nin karşısındaki en büyük güvenlik tehdidi olarak Rusya Federasyonu ve Çin ile girişilen uzun soluklu stratejik mücadele gösterilmektedir. Bu mücadele politik, ekonomik, toplumsal ve teknolojik alanlarda bu üç ülkeyi karşı karşıya getirmektedir. Rusya'nın vekalet savaşları, insansız hava araçları, robotik sistemler, nokta atışlı silah sistemleri ve sofistike siber güvenlik ve saldırı kapasitesi gibi alanlarda imkân ve kabiliyetlerini artırdığı belirtilmekte; Çin'in ise yapay zeka, hipersonik sistemler, robotik uygulamalar, malzeme bilimi, biyo-mühendislik, kuantum iletişim bilimleri, uzay teknolojileri ve biyometrik çalışmalar alanında ilerlemeler kaydettiği vurgulanmaktadır. Bu teknolojik yaklaşım ışığında geleceğin ordusunda teknolojik kapasitenin oldukça önemli bir bileşen olduğu, klasik konvansiyonel savaşların yerini vesayet savaşları ve teknolojik üstünlüğe dayalı mücadelelerin alacağı öngörülmektedir.

Afganistan ve Irak gibi istikrarsı ülkelerin durumu güvenlikleştirilerek, gerek $\mathrm{ABD}$ gerekse küresel anlamda bu ülkelerin demokratik yönetim ve serbest pazar ekonomisi ekseninde yeniden yapılandırılması bir çözüm olarak görülmüştü. Bu kapsamda askerî birlikler sadece düşmanı etkisiz hale getirmekle görevli silahlı yapılar olmanın ötesinde bu ülkelerde faaliyet gösteren silahlı sosyal sorumluluk projesi çalışanları gibi algılanmaktaydılar. Ancak değişen konjonktür ve bu kapsamlı mücadelenin maliyeti $\mathrm{ABD}$ hükümeti ve askerî karar verme mekanizmalarını bu tarz yaklaşımlardan uzaklaştırarak daha küçük birliklerle yürütülen GNH yöntemlerine yönlendirdi. Doğrudan sıcak çatışmalarda yer almanın yarattığı kayıpların minimuma indirilmesi açısından istihbarat destekli özel birlik harekâtlarının etkinliği üzerinde fikir birliğine varıldığı görülmektedir. Ancak daha önceki dönemlerde de olduğu gibi ABD politikalarının ve askerî stratejilerinin sürdürülebilirliğinin oldukça düşük olduğu söylenebilir.

İnternet Sayfas1, 2020, https://www.trtworld.com/magazine/who-will-win-a-hybridwar-between-the-us-and-iran-32817 (Erişim Tarihi: 17.08.2020). 
Bu durumun en net örneklerinden bir tanesi Taliban ile 29 Şubat 2020 tarihinde varılan barış antlaşmasıdır. Yaklaşık yirmi yıldır sürdürülen mücadelelerde başından beri Taliban'ı sürece dâhil etmeyen ve bu yönde birçok can kaybının verilmesine neden olan bir politika izlenmesinin ardından, elde edilen tüm kazanımları tehlikeye atabilecek bir süreç ortaya kondu. Yürütülen çabaların temel hedefi olarak demokratik Afgan yönetimini istikrarlı ve güvenilir tek meşru aktör olarak yeniden yapılandırmak olarak gösteren bu uzun soluklu çabalara rağmen barış antlaşması için oturulan masada Afgan Hükümetine yer verilmemesi oldukça tezat bir durumdur.

Geleceğin güvenlik algısı ve silahlı kuvvetlerin yapısı üzerine ortaya konan değerlendirmelerde GNH yaklaşımlarının temel nitelikleri olan bölgeyi ve halkı samimi bir şekilde tanıma ve ona göre hal tarzı belirleme yaklaşımlarının geri planda kaldığı görülmekte. Bu gibi sosyal bilimler tabanlı yaklaşımlar yerine daha somut ve teknoloji merkezli yaklaşımlara doğru bir kayma olduğu da göze çarpmakta. Bu yaklaşımda insansız hava araçları, yapay zekâ uygulamaları, iletişim imkânları, ağ savaşları, nükleer kapasiteler gibi kavramlar popülerlik kazanmıs durumda.

Kalpler ve zihinlerin kazanılmasına yoğunlaşan kapsamlı ayaklanmaya karşı koyma yaklaşımlarına alternatif olarak değerlendirilebilecek bir diğer yaklaşım da Eli Berman, Joseph H. Felter ve Jacob N. Shapiro tarafından yapılan Small Wars, Big Data (2018) isimli çalışmadır. Bu çalışmada ayaklanmaya karşı koyma harekâtının bilgi ve istihbarat merkezli bir mücadele olduğuna vurgu yapılmaktadır. İsyancıların yapılanmaları, amaçları ve eylemleri hakkında istihbarat elde edilebilme anlamında halkın önemli bir aktör olduğu, hükümet ve ayaklanmacıların tutumları karşısında bir karar verdiklerini değerlendirmektedir. Dolayısıyla, bu tür savaşlar hükümet, ayaklanmacılar ve halk arasında üçlü bir ilişkiye dayanmaktadır. Bu ilişkinin anlaşılması noktasında da analitik yaklaşımların takip edilmesi gerektiği ortaya konulmaktadır. Sadece literatür ve geçmiş tecrübelere dayalı geniş kapsamlı yatırım ve çabaların beklenen sonucu doğurmak için yeterli olmadığına dair örnekler verilmektedir. Ekonomik kalkınmanın ve istihdamın sağlanmasının Irak ve Afganistan'da ayaklanma harekâtlarının sona erdirilmesinde olumlu etki yaratacağına yönelik düşüncenin yapılan analitik incelemelerle gerçekçi olmadığı ortaya konulmaktadır. Yine kapsamlı ayaklanmaya karşı koyma yaklaşımı çerçevesinde Afganistan'da 
2010 yılında General McChrystal tarafından yürütülen çabalarda ülkenin güneyinde yer alan Marjah bölgesinin Taliban kontrolünden kurtarılarak halkın kazanılmasına yönelik büyük çaba sarf edildiği belirtilmekte, ancak 2014 sonrası koalisyon birliklerinin aktif operasyonlardan çekildiklerinde bölgenin önemli kesimlerinin Taliban kontrolüne tekrar döndügü ifade edilmektedir. ${ }^{61}$

$\mathrm{Bu}$ tür mücadelelerde, ayaklanmacilar üzerine gerekli bilgilerin akışının sağlanması amacıyla icra edildiği bölgenin sosyokültürel, ekonomik ve politik yapısı üzerine yapılacak analitik değerlendirmeleri başarının temel unsuru olarak görmektedir. Analizin oturduğu analitik zemin olarak da askerî tarih, istatistiksel analizler, iktisat ve sosyal bilimlerin bileşiminden bir bilimsel bakış açısı ve yapay zekâ uygulamaları olduğu anlaşılmaktadır. Bu alternatif yaklaşım kalplerin kazanılmasından çok halka tercih edebilecekleri mantıklı bir seçenek sunmayı, kinetik operasyonlar, kalkınma, bilişim teknolojileri ve bilgiye dayalı bilimsel analiz gibi kavramları küçük savaşların yeni odağı olarak görmektedir. Bilimsel analizlere örnek olarak sivil kayıplar, insansız hava araçlarının kullanımı, ekonomik kalkınma ve yerel yardımların yürütülen mücadeleye etkilerinin yapay zekâ uygulamaları verilmektedir. ${ }^{62}$

\section{Sonuç}

Tarihsel süreçte GNH güçlü olan karşısında güçsüz olanın hayatta kalabilmek adına kullandığı bir araç olmuştur. ABD Ordusu bu tarihsel süreçte konvansiyonel gücü nedeniyle genel olarak güçlü taraf olarak yer almış olup, GNH nispeten güçüz mütecaviz yapıların sıklıkla başvurduğu bir yol olarak değerlendirilmektedir. $\mathrm{Bu}$ anlamda gayrinizami harbin ulusal anlamda politika ve güvenlik çıarlarını muhafaza etmenin ve geliştirmenin geçerli bir aracı olup olmadığı ya da bu konvansiyonel karşılaşmaların bir tali unsuru olarak mı kalması gerektiği süre gelen temel tartışmaların başında gelmektedir. ABD özelinde halen akademisyen ve teorisyenler ordunun ne şekilde bir GNH yapılanmasına ihtiyacı olduğu, konvansiyonel kabiliyetlerin ne ölçüde korunması gerektiği ya da hibrit savaş formuna göre karmaşık bir yapı geliştirilmesi konuları üzerinde kafa yormaktadırlar.

${ }^{61}$ E. Berman et al., Small Wars, Big Data: The Information Revolution in Modern Conflict, Princeton University Press, Princeton, New Jersey, 2018.

${ }^{62}$ A.g.e. 
Ancak savunma, iletişim ve ulaşım teknolojileri alanında gerçekleşen baş döndürücü değişim savaş ve çatışmaların karakteristiğini de inanılmaz bir hızla değiştirmekte. Bu değişimin yol açtı̆̆ en ciddi ikilem ise, teknolojik imkânlar, yapay zekâ ve sayısal istihbarat değerlendirmelerinin kültürel faktörlere hâkimiyet, insan ve halk merkezli emek yoğun mücadelelerden daha mı etkili olduğu konusunda yaşanmakta. Bu bağlamda konvansiyonel olanla gayrinizami olan arasındaki sınırın neredeyse tamamen muğlaklaştığı bir süreç yaşanmaya başlandığı ifade edilebilir. Bu nedenle GNH kavramının taktik bakımdan farklılıklar göstermekle birlikte stratejik düşüncede kendisine mutlak bir yer bulacağı son derece doğru bir önerme olacaktır. Konvansiyonel güç olma iddiası ve küresel bir güvenlik politikası izleyen $\mathrm{ABD}$ için $\mathrm{GNH}$ hem tehdit değerlendirmesi boyutunda hem de mücadele yöntemi bağlamında kritik bir öneme sahiptir. Konvansiyonel anlamda Çin, Rusya, İran ve Kuzey Kore gibi devletleri tehdit unsuru olarak görse de $\mathrm{ABD}$ açısından bu ülkelerle farklı coğrafyalarda konvansiyonel olmayan mücadeleler üzerinden karşı karşıya gelineceği kabul edilmektedir. İçinde bulunulan bu dönemi anlamlandırmada ne konvansiyonel savaş ne de GNH tek başına yeterli gelmemektedir.

\section{Summary}

When the concept of irregular warfare is considered as armed conflicts or use of force for political purposes other than regular battles between the armies of two or more states in the broadest sense, it can be said that the experience of the US Army in this field goes back to the period of the American Civil War. However, the concept was systematically embedded in military structuring in its modern sense, coinciding with the Second World War period. In this period, the establishment of the Special Service Force under the Office of Strategic Services (OSS) in order to perform different functions such as obtaining intelligence behind the German lines, espionage and sabotage activities and organizing local resistances is remarkable.

In the Vietnam War, the struggles that could not be carried out with conventional army units turned into a counterinsurgency operation. According to this new approach, the operation to counter the insurgency was defined as not only an activity carried out by special forces, but a comprehensive struggle that should be carried out by the entire US Army. 
The experiences of this period were recognized by the documents written in the military literature such as FM 31-15 Operations against Irregular Forces, FM 31-16 Counterguerrilla Operations and FM 31-22 (A) US Army Counterinsurgency Forces. Although the Vietnam experience in theoretical and practical terms brought significant gains to the US military both structurally and doctrinally, the political and social negativities of the defeat caused the US Army to be suspicious of such wide-ranging counterinsurgency and irregular operations for a long time.

The mutual arms race created by the Cold War period unexpectedly left its place to a new era in terms of war and conflict with the dissolution of the Soviet Union. Ethnic conflict, insurgency and unstable governments that emerged in this new period brought the concept of irregular warfare back to the agenda. The US Army, which was declared victorious from the Cold War, was considered by military experts and strategists as the world's most superior conventional army with its structure based on technological superiority. Moreover, this conventional army was looking for different test areas with the enthusiasm of not having the opportunity to prove its technological possibilities and doctrinal superiority. The invasion of Kuwait by Iraq offered this test opportunity and the war that took place in the eyes of the whole world in a short time resulted in a victory that registered the conventional power of the USA at the strategic and operative level. During this war based on conventional superiority, irregular warfare was also seen as a secondary element.

However, with the deaths of eighteen US soldiers in Somalia, a serious hole was opened in the conventional armour of the US military, which was riveted with these successes. In response to this loss and damage to international reputation, such operations were approached with caution and no participation was maintained until the September 11 Attacks. After the attacks, the approach to resist the new insurgency based on the rapid change of the conventional perspective became the dominant concept of the struggles in Iraq and Afghanistan with a population-centric approach. However, the failure of these struggles and theoretical approaches to show the expected effect once again led to a cautious approach to irregular warfare activities, which manifested itself in the form of opposing the insurgency. Comprehensive state-building activities were replaced by a less risky and economical method of directing local elements in regions such as Syria by 
means of small private units and ensuring the control of these local elements through political support.

In line with the processes stated in this study, how the US Army's irregular war doctrine was shaped after the September 11 attacks and what it means in current strategic thinking is revealed. Understanding the importance of irregular warfare in the changing security concept of the USA in the light of official documents, military specifications and discussions in the literature constitutes the main purpose of the study. The study consists of three parts. In the first part, the irregular warfare approach of the USA before the September 11 attacks and the place of irregular warfare elements in the armed forces are examined. In the second part, the change and the rise of irregular war after the occupation of Afghanistan and Iraq are discussed. In the last section, current perspectives that are sceptical of comprehensive state building activities and based on the use of local elements are presented.

According to the analysis result; for the United States, which claims to be a conventional power and follows a global security policy, irregular warfare has a critical importance both in terms of threat assessment and method of struggle. Although it sees states such as China, Russia, Iran and North Korea as a threat in the conventional sense, it is accepted that these countries will face unconventional struggles in different geographies from the US point of view. Neither conventional warfare nor irregular warfare alone is sufficient to make sense of this period. The definition of neoconventional wars and the fact that conventional forces fight each other by irregular methods may be a suitable definition for this period.

\section{Çatışma Beyanı:}

Makalenin ile ilgili herhangi bir kurum, kurulus, kişi ile çıkar çatısması bulunmamaktadır. 
11 Eylül Terör Saldırıları Sonrası ABD Gayrinizami Harp Anlayışının Değişimi

Kaynakça

Kitaplar

BERMAN, E., J.H. Felter, J.N. Shapiro, and V. McIntyre. Small Wars, Big Data: The Information Revolution in Modern Conflict. Princeton, New Jersey: Princeton University Press, 2018.

BELL, Collen. The Police Power in Counterinsurgency: Discretion, Patrolling and Evidence In War, Police and Assemblages of Intervention, edited by Jan Bachmann, Colleen Bell and Caroline Holmqvist, 17-35, Routledge, New York, 2015.

CLINE, Lawrence E. Coindinistas Versus Whack-a-Mole: The Debate on Coin Approaches. In The Future of Counterinsurgency, edited by Lawrence E. Cline and Paul Shemella, 141-62, Praeger, California, 2015.

COCKBURN, Patrick. Chaos $\mathcal{E}$ Caliphate.: QR Books, New York and London, 2016. COOLEY, John K. Alliance against Babylon: The Us, Israel and Iraq. Pluto Press, London, 2005.

FOWLER, Christopher E. Forgeting Lessons Learned: The United States Army's Inability to Embrace Irregular Warfare. Air Command and Staff College, Air University, Alabama, 2014.

GIUSTOZZI, Antonio. Koran, Kalashnikov and Laptop : The Neo-Taliban Insurgency in Afghanistan. Hurst \& Company, London, 2007.

KILCULLEN, David. Out of the Mountains: The Coming Age of the Urban Guerrilla. Oxford University Press, New York, 2013.

KREPINEVICH, Andrew F. The Military-Technical Revolution: A Preliminary Assessment. Washington D.C.: Center for Strategic and Budgetary Assessments, 2002.

MANSOOR, Peter R. Introduction: Hybrid Warfare in History. In Hybrid Warfare: Fighting Complex Opponents from the Ancient World to the Present, edited by Williamson Murray and Peter R. Mansoor, 1-17. Cambridge: Cambridge University Press, 2012.

MCCHRYSTAL, Stanley A. My Share of the Task: A Memoir. Portfolio/Penguin, New York, 2013.

METZ, Steven, and MILLEN, Raymond. Insurgency and Counterinsurgency in the 21st Century: Reconceptualizing Threat and Response. Strategic Studies Institute, U.S. Army War College, Carlisle, PA, 2004.

MIGDAL, Joel S. Shifting Sands: The United States in the Middle East. Columbia University Press, New York, 2014.

MOCKAITIS, Thomas R. Trends in American Counterinsurgency. In The Routledge Handbook of Insurgency and Counterinsurgency, edited by Paul B. Rich and Isabelle Duyvestey, 251-62, Routledge, New York, 2012.

OWENS, Patricia. Economy of Force : Counterinsurgency and the Historical Rise of the Social. Cambridge Studies in International Relations. Cambridge, United Kingdom: Cambridge University Press, 2015.

RASHID, Ahmed. Descent into Chaos: The U.S. And the Disaster in Pakistan, Afghanistan, and Central Asia. Penguin Group, US, 2008.

RICKS, Thomas E. The Gamble: General David Petraeus and the American Military Adventure in Iraq, 2006-2008. New York: Penguin Press, 2009.

RYNNING, Sten. Nato in Afghanistan : The Liberal Disconnect. Stanford Security Studies, Palo Alto, CA, USA, 2012.

SEMPLE, Michael. Rhetoric, Ideology, and Organizational Structure of the Taliban Movement. United States Institute of Peace (Washington, D. C.: 2014).

TARZI, Amin. The Neo-Taliban. In The Taliban and the Crisis of Afghanistan, edited by Robert D. Crews and Amin Tarzi, 274-310. Harvard Univerity Press, USA, 2008.

UCKO, David H. The New Counterinsurgency Era: Transforming the U.S. Military for Modern Wars. Georgetown University Press, Georgetown, 2009. 
WEST, Bing. No True Glory: A Frontline Account of the Battle for Fallujah. Bantam Books, New York, 2005.

JABAR, Faleh A. In Tribes and Power: Nationalism and Ethnicity in the Middle East, edited by Faleh A. Jabar and H. Dawod, Saqi, London, 2003.

Doktora Tezi

ÖZDEMIR, Emrah. Post-Conflict Statebuilding as a Counterinsurgency Strategy: A Critical Analysis of Afghanistan, Swansea: Swanse University College of Art and Humanities, Yayımlanmamış Doktora Tezi, 2016.

\section{Makaleler}

BELL, Colleen. Civilianising Warfare: Ways of War and Peace in Modern Counterinsurgency. F Int Relat Dev 14, no. 3, 2011.

BIDDLE, Stephen, Jeffrey A. Friedman, and Jacob N. Shapiro. Testing the Surge: Why Did Violence Decline in Iraq in 2007?. International Security 37, no. 1, 2012.

BRAHIMI, Alia. The Taliban's Evolving Ideology. LSE Global Governance, London, 2010.

FARRELL, Theo, and Antonio Giustozzi. The Taliban at War: Inside the Helmand Insurgency, 2004-2012. International Affairs 89, no. 4, 2013.

KAGAN, Frederick W. Choosing Victory A Plan for Success in Iraq, American Enterprise Institute, 2007.

KILCULLEN, David. The Evolution of Unconventional Warfare. Scandinavian Fournal of Military Studies 2, no. 1, 2019, p. 61-71.

RICHARDS, David Julian. Commander's Foreword. ISAF Mirror, no. 30, July 2006.

RICKS, Thomas E. The Coindinistas. Foreign Policy, no. 176, 2009.

SEWALL, Sarah. Crafting a New Counterinsurgency Doctrine. Foreign Service Fournal, 2007.

UCKO, David H. Critics Gone Wild: Counterinsurgency as the Root of All Evil. Small Wars $\mathcal{E}$ Insurgencies 25, no. 1, 01.02.2014.

COONS, Kenneth C. Jr., and HARNED, Glenn M. Irregular Warfare Is Warfare. Features, no. 52, 2009.

Resmî Belgeler

FM 3-24. Counterinsurgency. Washington, DC: Headquarters Department of the Army, 2006.

- Insurgencies and Countering Insurgencies. Washington DC: Headquarters Department of the Army, 2014.

JP3-05. Special Operations. U.S.A.: DoD, Joint Chiefs of Staff, 2014.

- Special Operations. U.S.A.: DoD, Joint Chiefs of Staff, 2011.

Special Operations: Joint Chiefs of Staff, 1998.

Irregular Warfare (Iw) Foint Operating Concept (Foc). USA Department of Defense, 2007.

Office of Strategic Services. Operational Group Command. Washington D.C.: OSS Presentation, 1944.

PETRAEUS, David H., and James F. Amos. Foreword of Fm 3-24 Counterinsurgency. Headquarters Department of the Army, Washington, D.C., 2006.

SOPKO, John F. Why ANSF Numbers Matter: Inaccurate and Unreliable Data, and Limited Oversight of On-Budget Assistance Put Millions of U.S. Taxpayer Dollars at Risk, (Virginia: SIGAR, Apr 29, 2015).

The White House. Sustaining U.S. Global Leadership: Priorities for 21st Century Defense: Department of Defense, 2012.

U.S. Department of Defense. Quadrennial Defense Review Report. Edited by Department of Defense. Washington D.C.: Department of Defense, 2006.

İnternet Kaynakları

ATKINSON, Rick. Night of a Thousand Casualties. Washington Post, 1994. https://wapo.st/3m337sH/. (Erişim Tarihi: 18.08.2020). 
BEAUMONT, Peter. Stanley Mcchrystal: The President's Stealth Fighter. The Guardian, 26.09. 2009. http://www.theguardian.com/theobserver/2009/sep/27/stanleymcchrystal-commander-us-forces. (Erişim Tarihi: 18.09.2020).

DIZARD, Wilson. Who will win a 'hybrid war' between the US and Iran?, TRTWorld Internet Sayfasi, 2020, https://www.trtworld.com/magazine/who-will-win-a-hybridwar-between-the-us-and-iran-32817. Erişim Tarihi: 17.08.2020).

EVANS, Ryan. Coin Is Dead, Long Live the Coin. Foreign Policy (2020). https://foreign policy.com/2011/12/16/coin-is-dead-long-live-the-coin/. (Erişim Tarihi: 26.09.2020).

KREPINEVICH, Andrew F. How to Win in Iraq. Foreign Affairs 85, No.5, no. September/October 2005. http://www.foreignaffairs.com/articles/61024/andrew-fkrepinevich-jr/how-to-win-in-iraq. (Erişim Tarihi: 16.08.2020).

MCCARTHY, Rory. Amnesty Details Killing of Civilians by British Soldiers. The Guardian, 2004. https://www.theguardian.com/world/2004/may/11/military.iraq. (Erişim Tarihi: 06.07.2020).

NAGL, John A. Isaf Campaign Plan Summary. Small Wars Fournal. November 19, 2008. http://smallwarsjournal.com/blog/isaf-campaign-plan-summary. (Erişim Tarihi: 18.09.2020). 